NBER WORKING PAPER SERIES

\title{
CAN FIXED-TERM CONTRACTS PUT LOW SKILLED YOUTH ON A BETTER CAREER PATH? EVIDENCE FROM SPAIN
}

\author{
J. Ignacio García-Pérez \\ Judit Vall Castelló \\ Ioana Marinescu \\ Working Paper 22048 \\ http://www.nber.org/papers/w22048 \\ NATIONAL BUREAU OF ECONOMIC RESEARCH \\ 1050 Massachusetts Avenue \\ Cambridge, MA 02138 \\ February 2016
}

Our thanks to A. Hijzen, S. Bentolila, and A. Novo for all their comments, and to the audience at Harris School of Public Policy (Chicago), the OECD Employment Directorate, the SAEe 2013 (Santander), the 8th IZA/World Bank Conference on Employment and Development, (Bonn), THEMA(University of Cergy-Pointoise, Paris), the ESPE-2014 (Braga), the Workshop on "Labour Markets during crises" (NUY Maynooth), the 3rd SEEK Conference at ZEW, Mannheim, the SOLE/EALE world meetings in Montreal 2015. J. Ignacio Garcia Perez acknowledges financial support from the Spanish Ministry of Economics and from the Regional Government of Andalusia (research grants no. SEJ-6882/ECON and ECO2010-21706). Judit Vall Castello acknowledges financial support from the Spanish Ministry of Economics and Competition (research grant ECO201231081). The views expressed herein are those of the authors and do not necessarily reflect the views of the National Bureau of Economic Research.

NBER working papers are circulated for discussion and comment purposes. They have not been peerreviewed or been subject to the review by the NBER Board of Directors that accompanies official NBER publications.

(C) 2016 by J. Ignacio García-Pérez, Judit Vall Castelló, and Ioana Marinescu. All rights reserved. Short sections of text, not to exceed two paragraphs, may be quoted without explicit permission provided that full credit, including $(C$ notice, is given to the source. 
Can Fixed-Term Contracts Put Low Skilled Youth on a Better Career Path? Evidence from Spain

J. Ignacio García-Pérez, Judit Vall Castelló, and Ioana Marinescu

NBER Working Paper No. 22048

February 2016

JEL No. J3,J41,J48,J64

\section{ABSTRACT}

By reducing the commitment made by employers, fixed-term contracts can help low-skilled youth find a first job. However, the long-term impact of fixed-term contracts on these workers' careers may be negative. Using Spanish social security data, we analyze the impact of a large liberalization in the regulation of fixed-term contracts in 1984. Using a cohort regression discontinuity design, we find that the reform raised the likelihood of male high-school dropouts working before age 19 by $9 \%$. However, in the longer run, the reform reduced number of days worked (by $4.5 \%$ ) and earnings (by $9 \%$ ).

J. Ignacio García-Pérez

Universidad Pablo de Olavide

jigarper@upo.es

Judit Vall Castelló

Centre for Research in Health and Economics

Universitat Pompeu Fabra

Ramon Trias Fargas 25-27

08005 BARCELONA (SPAIN)

judit.vall@upf.edu
Ioana Marinescu

Harris School of Public Policy

University of Chicago

1155 East 60th Street

Chicago, IL 60637

and NBER

ioanamarinescu@uchicago.edu 


\section{Introduction}

European countries typically have a high level of employment protection legislation (EPL), making it expensive to dismiss workers on permanent contracts. While EPL does not reduce overall employment, it has an adverse effect on the employment of workers with low and hard to observe productivity, such as youth (OECD, 2006). To address this problem, a number of European countries have made it easier for firms to use fixed-term contracts with lower firing costs. It was hoped that fixed-term contracts would help improve the labor market outcomes of low skilled workers in high EPL countries.

But do fixed-term contracts really help? In theory, fixed-term contracts, by decreasing firing costs, can help workers with uncertain credentials obtain employment. Moreover, fixed-term contracts may help workers accumulate human capital as well as gain contacts that can allow them to obtain better jobs in the future. On the other hand, there is a danger that workers go from fixed-term contract to fixed-term contract, leading to lower employment stability and no progression towards better jobs (Blanchard and Landier, 2002). In theory, the impact of fixed-term contracts on the labor market outcomes of affected workers is therefore ambiguous.

The empirical evidence on the impact of fixed-term contracts and temporary work on the labor market outcomes of affected workers is also mixed. A number of papers examine the stepping stone hypothesis according to which temporary work helps workers land permanent jobs. The evidence at the European level is mixed, with some papers finding evidence of the stepping-stone hypothesis (D'Addio and Rosholm (2005); Booth, Francesconi and Frank (2002), among others) while some other papers find that temporary contracts do not improve access to permanent contracts (Zijl, Van Den Berg and Heyma, 2004). The evidence on temporary help jobs is also mixed with the best identified study finding a somewhat negative impact of temporary work on earnings and employment in the US (Autor and Houseman, 2010), while studies using European data find a positive effect of temporary help jobs on securing permanent employment (e.g. Ichino, Mealli, and Nannicini, 2008).

Even if fixed-term contracts can help workers secure permanent jobs, the long-term effects of easily available fixed-term contracts remain uncertain. Indeed, when workers lose a permanent job, they may be back on a fixed-term contract and their return to stable employment may be delayed. The current literature only addresses the impact of temporary 
work within a few months to a few years of the first temporary job, and the long-run impact remains unknown.

Another limitation of the existing literature is that it compares people who did and did not use temporary contracts (or temporary help agencies) within a given regulatory framework. This research cannot therefore directly inform us about what happens when the regulation of temporary work becomes less stringent. With a laxer regulation of fixed term contracts, some unemployed workers may get a fixed term contract fairly quickly and then transition to a permanent contract. However, it is possible, that, were fixed term contracts not easily available, the same workers would have transitioned to a permanent contract even more rapidly. Therefore, even if we believe the stepping stone hypothesis that, for an unemployed worker, taking a fixed term contract is better than staying unemployed, this does not imply that making fixed term contracts more easily available will increase the proportion of low skilled workers in permanent contracts and benefit their careers. Overall, both the long-term impact of temporary work on careers, and the overall impact of fixedterm contract regulation remain open questions.

In this paper, we use Spanish social security data to assess the long-term impact of fixedterm contract regulation on employment and earnings. Spain is an ideal ground for our research because fixed-term contract use was liberalized early and Spain subsequently became the OECD country with the highest share of fixed-term contracts (Dolado et al., 2002). To assess the impact of fixed-term contracts, we track cohorts of workers who enter the labor market before and after a 1984 reform that liberalized the use of fixed-term contracts. We focus specifically on male high school dropouts because they are most likely to be affected by the liberalization of this type of contracts. We assign their age of labor market entry to be 16 as this is the minimum legal age to work in Spain and we know that those individuals are high school dropouts.

Thus, using a cohort discontinuity design (see e.g. Borghans et al., 2014), we show that, compared to workers who entered the labor market (turned 16) in the trimester just before the reform, workers who enter the labor market (turned 16) in the trimester after the reform experience a larger probability of working before age 19. However, workers who enter the labor market after the reform also experience both lower days of work and lower earnings over their subsequent career. We find that these losses are largest in the first ten years of these workers' careers. Based on the first ten years of potential labor market experience, and after controlling for year and experience fixed effects, we estimate the loss in terms of 
days of work to amount to 9.8 days per year (4.5\% of average days worked). The earnings loss is as high as 9\% per year. Even for workers with more than ten years of potential experience, the reform still has a significant, if smaller, negative effect on days worked and earnings. Over 27 years of these high school dropouts' careers, yearly earnings losses due to the liberalization of fixed term contracts amount to $7.5 \%$, a large and persistent effect.

We perform the same analysis for male high school graduates and find no effect of the reform on days worked or earnings in the first ten years in the labor market. Using the high school graduates as a control group, we can re-estimate the impact of the reform on high school dropouts. In this difference-in-differences specification, we find a statistically significant negative effect of the reform on days worked and earnings that is of similar magnitude to the results based on the cohort discontinuity alone. These difference-indifferences results alleviate the concern that the estimated impact of the liberalization of fixed-term contracts on high school dropouts is biased by other concurrent changes in the labor market.

We also investigate the channels through which the reform negatively affects the careers of male high school dropouts. One of the reasons why greater fixed-term contract availability at the beginning of a worker's career has a negative impact on long-run career outcomes is that workers are more likely to work under non-permanent contracts well after labor market entrance. This situation further exposes workers to the well known wage penalties associated to both unemployment and temporary work.

This paper makes two key contributions to the literature. First, while previous literature on the labor market impact of fixed term contracts has relied on regression adjustments and other non-experimental techniques for identification, we use a cohort discontinuity design and a difference-in-differences strategy that exploit a large change in Spanish regulation. Second, our paper innovates by examining the long-term impact of fixed-term contracts on young people's career: Social Security data allows us to have more than 20 years of follow up whereas previous literature examined outcomes over at most a few years. While most of the previous literature on European labor markets finds a positive short run effect of fixedterm contracts and temporary work, we find a negative impact of fixed term contracts on labor market outcomes in the long run. Our results are most similar to the quasiexperimental study of temporary help jobs in the US (Autor and Houseman, 2010). We conclude that the combination of examining long-run outcomes and using a quasiexperimental design allows us to uncover substantial and previously undocumented 
negative effects of lax fixed-term contract regulation on the long-term labor market outcomes of low-skilled youth.

There have been a number of previous papers examining the use of fixed-term contracts in Spain, but focusing on somewhat different issues from our paper. ${ }^{1}$ First, the previous literature has examined the impact of fixed-term contract duration on the probability of finding a permanent job. Most of those papers (see for example Güell and Petrongolo (2007) or García-Pérez and Muñoz-Bullón (2011)) agree that the effect of temporary contract duration on the probability of finding a permanent job is slightly increasing with tenure at the temporary contract but mainly concentrated at specific durations of the temporary contract $(6,12,24$ - the typical duration of these contracts-, and specially at the $36^{\text {th }}$. month, the maximum duration of such contracts in Spain). Second, the paper by Rebollo (2011) stresses the idea that not only the number of temporary contracts and job interruptions are important in determining the chances of a worker to find a permanent contract but also the number of firms for which this person has worked is an important determinant. Therefore, accumulating temporary contracts with the same firm reduces the probability of getting a permanent contract while moving from one firm to another with a temporary contract increases the chances of getting a permanent contract. Third, the literature has examined the impact of fixed-term contracts on firms' outcomes. Using the simulations of a dynamic labor demand model, Aguirregabiria and Alonso-Borrego (2014) evaluate the effects of the same labor market reform we are analyzing: the liberalization of fixed term contracts in 1984. They find that both total employment ${ }^{2}$ and job turnover increased due to the reform in Spanish manufacturing firms.

Our paper is also related to a literature that examines the long-term labor market impact of entering the labor market under high unemployment. Kahn (2010), Moulton (2011) and Oreopoulos et al. (2012) all find negative long-run wage effects of entering the labor market under adverse economic conditions. Our work complements this literature by examining the long-term impact of policy rather than macroeconomic conditions. Although our regression discontinuity model identifies the impact of the policy by comparing two

\footnotetext{
${ }^{1}$ Some recent papers as Bentolila, Cahuc, Dolado and Le Barbanchon (2012) or Costain, Jimeno and Thomas (2010) analyze the effect of temporary contracts in Spain within the current context of economic crisis. The former explores the extent to which the significantly larger increase in unemployment in Spain, versus France, during the ongoing recession can be accounted for by the difference in EPL between the two countries. The latter studies the extent to which the coexistence of permanent and temporary jobs accounts for the volatility of employment in Spain. An also recent paper by Fernández-Kranz et al. (2015) finds that having a permanent contract partially protects Spanish women against the part-time/full-time wage gap.

${ }^{2}$ Examples of other papers analyzing the impact of employment protection legislation on firm outcomes are Autor, Kerr and Kugler (2007) for the US, and Cingano et al. (2015) for Italy.
} 
cohorts that enter the labor market only one trimester apart, in the robustness test section we provide additional evidence that our results are not driven by different labor market conditions at entry in these two consecutive trimesters.

The paper proceeds as follows. In section 2, we discuss the history of temporary contracts in Spain. Section 3 describes the data and the empirical strategy. Section 4 presents the results and some discussion and robustness checks are performed in section 5 . Section 6 concludes.

\section{History and current rules of temporary contracts in Spain}

\section{Historical background}

During the time of Franco's regime, the Spanish labor market was heavily regulated with a single trade union to which both employers and employees had to belong and with strong labor regulations to protect employment. This meant that, in reality, all jobs were full-time jobs of a permanent nature. After Franco's death in 1975 changes were introduced to relax some of the previous regulations. The most important one was the legalization of free trade unions and the abolishment of the single trade union in 1977.

It was not until 1980 that the strongest modernization of the labor relations system was introduced in Spain with the approval of the Workers' Statute. This law assumed every contract to be an open-ended contract as a general case, whereas temporary contracts were intended to be used only for jobs whose nature was temporary (seasonal jobs, temporary substitution of permanent workers, etc). Furthermore, the Worker's Statute kept most of the restrictions on dismissals. Dismissed permanent workers would receive severance payments that depend on whether the dismissal is fair or unfair. For fair dismissals, severance payments equal to 20 days of salary per year of job tenure with a maximum of one year wages, while for unfair dismissals severance payments amount to 45 days with a maximum of 42 months of wages. The reasons for the dismissal to be considered as fair are twofold: either the firm argues that the employee is incapable of performing his/her tasks or it argues that there are economic or technological reasons that require the dismissal of the worker. If a worker is dismissed under a fair dismissal by the firm but he/she does not agree with the fairness of the process, he/she can sue the firm and a legal process begins in which the firm has to pay the legal costs (in any case) as well as the wages of the worker if the dismissal is finally judged to be unfair by the court. In reality, labor courts effectively ruled most dismissals as unfair and so the costs of the legal process were usually higher for 
the employer than the severance payment for unfair dismissals. Although temporary contracts had a much lower severance payment (8 days per year of seniority), the restrictions on the use of this type of contracts meant that their use was very limited during the first half of the 1980s (Aguirregabiria and Alonso-Borrego, 2014; García-Pérez and Muñoz-Bullón, 2011).

During the first half of the 1980s, the Spanish unemployment rate experienced a rapid growth and it went over 20\%. This event prompted the Spanish government to introduce a new reform in $1984 .^{3}$ This was the first reform designed to liberalize the use of temporary contracts and to reduce dismissal costs for this type of contracts. The most important element of the reform is the fact that it eliminated the requirement that the activity associated with a temporary contract had to be of a temporary nature. Therefore, firms whose activities are not of a temporary nature could sign temporary contracts with any type of worker after the reform of 1984 . These contracts can be signed for a period between a minimum of six months and a maximum of three years. After the three years, the contract cannot be renewed, and the worker must either be fired (in this case, the employer cannot hire any other worker for that job and has to wait for at least one year to hire the same worker) or must be offered a permanent contract by his/her current employer. Furthermore, another advantage of this type of contracts is that firing costs at termination are very low (8 days per year of tenure but they can even be zero in some cases) and this termination cannot be appealed in front of the courts. The reform in 1984 did not alter any of the conditions for permanent contracts explained above (Aguirregabiria and Alonso-Borrego, 2014), which made temporary contracts even more appealing for firms.

As a result of this legislative change, the proportion of male employees aged 15-24 under temporary contracts increased from less than $40 \%$ to over $70 \%$ in less than five years after the approval of the reform, as can be seen in Figure 1. ${ }^{4}$ Between 1985 and 1994, over 95\% of all new hires were employed through temporary contracts and the conversion rate from temporary into permanent contracts was only around 10\% (Güell and Petrongolo 2007). Thus, the main concern with the liberalization of temporary contracts after 1984 was that it generated a huge segmentation in the Spanish labor market between unstable low-paying jobs and stable high-paying jobs, without helping to reduce unemployment.

\footnotetext{
${ }^{3}$ The law was passed in August 2nd 1984 and the full implementation of the law was established in a "Real Decreto" in October 1984.

${ }^{4}$ The rate of temporary employment in the Spanish labor market as a whole moved from less than $10 \%$ to over $30 \%$ in the same period. Data in Figure 1 is taken from the Spanish Labor Force Survey, which only reports information on the type of contract (temporary/permanent) from 1987. In the following section, we present evidence to show that the use of temporary contracts was very small before the 1984 reform.
} 
Shifting direction in light of these concerns, in 1994 new regulations limited the use of temporary employment contracts to seasonal jobs. In addition, the 1994 reform slightly relaxed dismissal conditions for permanent contracts. In particular, the definition of fair dismissals was widened by including additional "economic reasons” for them. In practice, however, employers continued to hire workers under temporary contracts for all types of jobs and not just for seasonal jobs. This perceived ineffectiveness of the 1994 reform led to a new reform in 1997, which was eventually extended in 2001. As with the 1994 reform, the goal of the 1997 and 2001 reforms was to reduce the use of temporary contracts. The 1997 reform created a new type of permanent contract, with lower severance costs in case of unfair dismissal (33 days per year of seniority) and with fiscal incentives in the first two years of the contract (i.e., reductions of employers' payroll taxes). ${ }^{5}$ However, rather than trying to limit the use of temporary contracts by further possibly ineffective regulation, these new reforms widened the employers' incentives to hire workers from certain population groups under permanent contracts. ${ }^{6}$ The 2001 reform essentially extended the 1997 reform by applying lower subsidies to more worker groups than the previous reform (García-Pérez and Muñoz-Bullón, 2011). The consequences of these subsidies, however, have not been a reduction in the use of temporary contracts or an increase in workers' employment stability but, on the contrary, only negligible effects on both dimensions because of the important side-effects (basically substitution effects) such subsidies have entailed (see García-Pérez and Rebollo, 2009).

\section{Evolution of temporary contracts in Spain}

Although the Spanish Labor Force Survey only reports information on the type of contract from 1987, some data from a report published in 1988 (Mateos and Sebastián, 1988) show that temporary contracts represented a very low percentage of the total number of nonagricultural private sector employees in 1983 (below 3\% until 1986). We can see in Figure 2 that the number of temporary contracts increased from the last trimester of 1984 when the new legislation on temporary contracts was passed.

\footnotetext{
${ }^{5}$ This was the first time (in 1997) since the Workers' Statute in 1980 that severance costs were changed for permanent workers in Spain.

${ }^{6}$ In particular, the 1997 reform reduced dismissal costs for unfair dismissals by about $25 \%$ and payroll taxes between $40 \%$ and $90 \%$ for newly signed permanent contracts and for conversions of temporary into permanent contracts after the second trimester of 1997 for workers under 30 years-old, over 45 years-old, the long-term unemployed, women under-represented in their occupations, and disabled workers (see, in this respect, Kugler et al. 2005)
} 
On the other hand, the Spanish Labor Force Survey shows that the proportion of temporary contracts as a percentage of total employment was around $10 \%$ at the beginning of 1987 and was already around 35\% in the mid-1990s. Therefore, very soon after the introduction of the 1984 reform, Spain was the country in Europe with the highest proportion of temporary contracts and this rate has been approximately three times larger than the average in OECD countries and approximately 2.5 times higher than the average in Europe until the second half of the 2000s (see Figure 1).

It has been widely recognized that the group of workers that has been most affected by the widespread use of temporary contracts in the Spanish economy is the youngest group of workers that enters the labor market. If we look at data from the OECD in Figure 1, we can see that the share of temporary contracts for the group of workers aged 15-24 was already $37.5 \%$ in 1984 (as opposed to $15.6 \%$ for the whole population of workers). If we restrict this age group even further, the Spanish Labor Force Survey shows that temporary contracts represented almost $50 \%$ of total employment for the age group 16-19 already by 1987 (as opposed to $15.6 \%$ for the whole population).

Again, data on temporary contracts before the introduction of the 1984 reform for the group of young workers is difficult to find but the same report mentioned above (Mateos and Sebastián, 1988) contains data on the number of apprenticeship contracts (which represent one part of the group of temporary contracts) from 1981 to 1986 as well as data on the percentage of these contracts with respect to the group of employees in the non-agricultural private sectors aged 16-19. We can see in Figure 3 that the percentage of these contracts for the group of individuals aged 16-19 increased from around 2\% before 1984 to $15-16 \%$ in 1985 and 21\% in 1986. Again, this represents only one type of temporary contracts (apprenticeship contracts) and for one group of workers (non-agricultural private sector workers) but it is quite impressive how the use of these contracts has increased since 1984.

Therefore, as our aim in this paper is to disentangle the long-term effects of the 1984 reform we will use a regression discontinuity strategy comparing high-school dropout men who reach the labor market entry age of 16 before and after the reform. As we have seen that this group of individuals is the most likely to be affected by the 1984 reform, we will compare individuals that entered the labor market when temporary contracts were not widely available with individuals that had their first labor market experience when the main restrictions for the use of temporary contracts were abolished. Therefore, even if we do not have individual information on the type of contract held in the first job, we know from 
previous evidence that just $2 \%$ of young workers had a temporary contract before the reform while $21 \%$ of them had a temporary contract by 1986 and almost 50\% by 1987 . Our aim is to understand whether entering the labor market under two very different labor market situations (with or without widely available temporary contracts) had any effect on long-term labor market outcomes.

\section{Data and empirical strategy}

\section{Data}

This study will use the Continuous Sample of Working Lives ("Muestra Continua de Vidas Laborales”, MCVL) which is a microeconomic dataset based on administrative records provided by the Spanish Social Security Administration. Each wave contains a random sample of $4 \%$ of all the individuals who had contributed to the social security system (either by working or being on an unemployment scheme) or had received a contributory benefit (such as permanent disability, old-age, etc.) during at least one day in the year the sample is selected. Hence, the sample is not including those individuals without any contact to Social Security in such a year. This may create some risks of sample selection, especially among women, immigrants or young workers. Hence, in order to minimize the potential selection effects, we combine the database for seven waves, from 2006 to 2012. That is, we have everybody that had a relationship of at least one day during this seven year period with the Social Security administration. For them, we have their complete labor market history observed in the data. In our sample, we select the cohorts born between 1965 and 1972 so that individuals are aged 34-47 during 2006-2012. Therefore, it is very rare for native men at these ages not to have any relationship of at least one day with the Social Security administration during a seven year period. This may be a potential problem, however, for women or immigrants in the sample as they have a more interrupted and discontinuous labor market trajectory. Therefore, we restrict the analysis to the native male sample.

There is information available on the entire employment and pension history of the workers, including the exact duration of employment, unemployment and disability or retirement pension spells, ${ }^{7}$ and for each spell, several variables that describe the

\footnotetext{
${ }^{7}$ As explained in, for example, Garcia-Perez and Rebollo (2009), there exists a potential issue of measurement error in the number of employment and unemployment spells and their duration given that firms can offer contracts for very short periods but subsequently recall workers. When this occurs, we treat the employment spell as a continuous period, despite the short interruption that appears in between. More
} 
characteristics of the job or the unemployment/pension benefits. There is also some information on personal characteristics such as age, gender, nationality and level of education.

Our main sample includes all high-school dropout native males who were born between the first trimester of 1965 and the fourth trimester of 1972. We determine their trimester of labor market entry to be the trimester they turn 16 as the minimum working age in Spain is set at 16 years old and these individuals are high school dropouts. Thus, we can compare cohorts who experienced the same labor market conditions, except that some entered the labor market in a tightly regulated fixed term contracts regime while others entered the labor market in a laxer fixed term contract regime. ${ }^{8,9}$ It is important to realize that we are not comparing a whole career spent under restrictive or lax fixed term contract regulation, but two careers, both exposed to lax fixed term contract regulation for most years, but that differ in the fixed term contract regulation in the first trimester of the career. As the reform was fully implemented by October 1984, individuals born in the third trimester of 1968 are used to determine what happens with a tight regulation of fixed-term contracts at entry whereas individuals born in the fourth trimester of 1968 (who turn 16 in Oct-Dec 1984) are used to assess what happens with a lax regulation of fixed-term contracts as they reach the age of labor market entry after the implementation of the reform.

We have 24.934 native males in the sample of high school dropouts, 14.732 workers born between 1962 and 1968 and 8.327 born between 1969 and $1975 .{ }^{10}$ Descriptive statistics of the variables included for our sample can be found in Table 1 and Table 2 .

On top of our main sample of high school dropouts, we also use a sample of 68.611 native male high school graduates. This sample is used to examine the impact of the reform on a group of workers who are more educated and should therefore experience fewer difficulties

specifically, we unify successive registers when they correspond to the same worker in the same firm with the same type of contract, and when the interruption lasts for less than 15 days.

${ }^{8}$ The minimum legal age for working in Spain was 14 before 1980 and 16 since that year. However, in 1977 there was already a regulation that increased the age to 16 years old. As can be seen in Figure 11 in the appendix, essentially no one in our oldest cohort born in 1965 was working before age 16, so the working patterns anticipated the change in the minimum legal age of working. We drop the few individuals who start working before age 16 .

${ }^{9}$ As individuals can enter the labor market after the age of 16 , we impose an extra sample restriction to include only those workers that begin working before age 21 in order to gain in sample homogeneity. Therefore, we interpret these results as an "intent-to-treat" estimation.

${ }^{10}$ The wage data is subject to bottom and top coding but the incidence of this in our estimation sample is quite low: there is no bottom code due to the possibility of working part-time and the percentage of workers in our sample with a wage in the top code is just 3.6\%. 
in the labor market. For this sample, we retain cohorts born in 1962-1969, ${ }^{11}$ and we keep only individuals who start working before age 22. In this sample, the first trimester cohort that could be affected by the reform is the cohort born in the first trimester of 1966. Indeed, in Spain, the cutoff for entering school is in January. So, those who are born in the first trimester of 1966 can graduate from high school in the summer of 1984 at the earliest and be affected by the liberalization of fixed-term contracts in the fall of 1984. In contrast, those who were born in the last trimester of 1965 can graduate from high school in 1983 the earliest, and would not be affected by the reform during their first year in the labor market if they graduated on time.

We will look at the effect of the reform on several labor market outcomes measured over the individual's labor market career. These outcomes include the number of non-permanent employment spells, the number of days worked, and the logarithm of the earnings.

\section{Empirical strategy}

We analyze the effect of the reform on a set of labor-market outcomes measured yearly. The key explanatory variable is the trimester of birth cohort, since this determines whether individuals enter the labor market before or after the liberalization of fixed-term contracts. We define the trimester of birth cutoff as the fourth trimester of 1968: that is, we consider as treated the cohort who turns 16 in October-December 1984, and older cohorts as untreated by the new policy at labor market entry (both cohorts are potentially affected in later years). Indeed, the law liberalizing fixed term contracts was passed in August 1984 but was only fully implement in October 1984. In robustness tests (Table 9 and Table 10), we will check the sensitivity of our results to dummying out the transition cohorts, i.e. those who turn 16 in the third or fourth trimester of 1984.

We expect the impact of the liberalization of fixed-term contracts to be stronger in the first ten years in the labor market. Therefore, we first restrict the data to the first ten years of potential labor market experience for each cohort (we will also show results with all years). We then collapse the individual data at the level of trimester of birth cohort (c) and calendar year (t), like in Oreopoulos et al. (2012). We collapse the data by year and not just by cohort in order to be able to add the following controls: year fixed effects to account for macro factors, and potential experience fixed effects. The data is collapsed at the calendar

\footnotetext{
${ }^{11}$ We have some missing values for wages for cohorts born 1962-1963 because wages were not properly measured (or were missing) in this dataset before 1990.
} 
year level and not at the trimester level because the outcomes in the data such as earnings or days worked are only observed at the calendar year level.

We run the following baseline specification for the cohort discontinuity design (weighing by cell size):

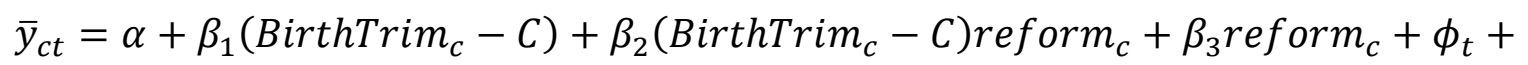

$\gamma_{c t}+u_{c t}$

Where the cutoff point $\mathrm{C}$ is the cohort born in the fourth trimester of 1968 . The model includes a linear cohort trend consisting of a birth year cutoff $(\mathrm{C})$ subtracted from the cohort's birth trimester (BirthTrim ${ }_{c}-C$ ) which estimates the trend ${ }^{12}$ in the outcome variable analyzed, for all birth cohorts. This trend is then interacted with the reform

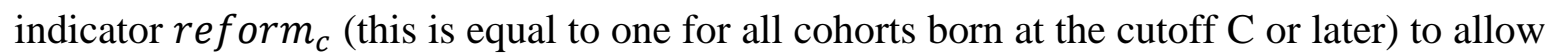
for a change of trend in the post-reform cohorts. $\phi_{t}$ is a calendar year fixed effect and $\gamma_{c t}$ is a years of potential labor market experience fixed effect, and $u_{c t}$ is the error term. We cluster the standard errors by cohort.

The variable that captures the effect of the policy is reform equals 1 if the individual is born at or after the trimester cutoff, so that $\beta_{3}$ is the shift in the intercept of the post-cutoff trend which represents the effect of the treatment. How can the coefficient of interest $\beta_{3}$ be interpreted? For example, when log earnings is the outcome $\bar{y}_{c t}, \beta_{3}$ tells us the percentage effect impact of the liberalization of fixed-term contracts on annual earnings (on average over the career), and after accounting for macro variables (time effects,$\left.\phi_{t}\right)$ and labor market experience $\left(\gamma_{c t}\right)$. Accounting for years of labor market experience is particularly important when earnings are on the left-hand side, since experience has a strong impact on earnings in the first years of a workers’ career.

In order for the effect to be correctly identified, regression discontinuity models require that the running variable (in our case the trimester of birth) cannot be manipulated so that the probability of being on each side of the discontinuity is exogenous. This is obviously satisfied in our sample for the date (trimester) of birth. However, as we also select individuals that are high-school dropouts in order to assume that they enter the labor market at age 16, it could be the case that the reform affected the probability of individuals

\footnotetext{
${ }^{12}$ We have also estimated the model with higher-order polynomials for the cohort trend (Table 9 and Table 10).
} 
studying more or less. In this case, we would observe a jump in the number of individuals in our sample for the cohort entering the labor market after the implementation of the reform. We can see in Figure 4 that this is not the case, as the percentage of men of each cohort who are high-school dropouts, and therefore are in our sample, declines over time. This is a steady decline due to the progressive increase in the amount of education for each subsequent cohort and we can observe that there is no discontinuity for individuals born in the fourth trimester of 1968.

In Table 3, we also formally test ${ }^{13}$ for an impact of the reform on the probability of dropping out of high school. We restrict the sample to males who are either high school dropouts or high school graduates. We find no significant impact of the reform on dropping out of high school, whether we use a linear (col. 1-2) or quadratic (col. 3-4) trend for birth cohorts. We thus conclude that the reform did not affect high school graduation.

The key identification assumption for the cohort discontinuity design is that the only discontinuous change at the cutoff is the liberalization of fixed-term contracts. In practice, the concern is that there may be important changes in the Spanish labor market in the fourth trimester of 1984 as compared to the third trimester of 1984 (when our treated and control cohorts respectively enter the labor market) and that these changes could bias our estimate of the impact of the reform. To address this concern, we use a control group: male high-school graduates. We expect the liberalization of fixed-term contracts to have less of an effect on high-school graduates because they tend to be more employable than highschool dropouts (Blazquez Cuesta (2008) and Dolado et al. (2013), among others, document this fact for the Spanish case). We first estimate the impact of the reform on male high-school graduates using the same cohort discontinuity design as for the high-school dropouts (equation 1), and restricting the data to the first 10 years in the labor market. We then use a difference-in-differences specification where the data is collapsed by trimester of birth, year, and education $(e)$ :

$\bar{y}_{e c t}=\alpha+\beta_{1}\left(\right.$ BirthTrim $\left._{c}-C_{e}\right)+\beta_{2}\left(\right.$ BirthTrim $\left._{c}-C_{e}\right)$ reform $_{c e}+\beta_{3}$ reform $_{c e}+$

$\beta_{4}$ treat $_{e}+\beta_{5}$ treat $_{e}$ reform for $_{c e}+\phi_{t}+\gamma_{c t}+u_{c t}$

This specification is similar to the previous specification (1). The cutoff $C_{e}$ is now specific to an education group: the cohort born in the last trimester of 1968 for high school dropouts, and the cohort born in the first trimester of 1966 for high school graduates (for

\footnotetext{
${ }^{13}$ We cannot use the popular McCrary (2008) test because our forcing variable, trimester of birth, is not sufficiently close to being continuous.
} 
high school graduates to enter the labor market in the fall of 1984, they must have graduated in the summer of 1984). The post-reform cohort indicator reform re $_{\text {is }}$ also specific to an education group. The dummy treat $_{e}$ is equal to 1 for high school dropouts and 0 otherwise. The difference-in-differences estimate is the coefficient $\beta_{5}$ on the interaction between the high school dropout dummy and the post-reform cohort dummy.

\section{Results}

We are interested in evaluating the long-term impact of entering the labor market under a regime where fixed term contracts are easy for firms to use. Specifically, we would like to answer the following question: does greater availability of fixed term contracts lead to more days of employment and higher accumulated earnings in the long run?

\section{Number of non-permanent contracts and labor market insertion}

We first investigate whether the reform led to a greater number of fixed-term contracts or non-permanent contracts ${ }^{14}$ using the cohort discontinuity design described by equation (1). Because the data on the type of employment contract is low quality before 1990, we use years 1990-2012 to assess the impact of the reform on the number of fixed-term and nonpermanent contracts. In Table 4, Panel A, we find that the impact of the reform on the number of fixed-term contracts is positive but falls short of statistical significance (P-value of 0.14 in col. 2) for high school drop-outs. The impact of the reform on high-school graduates is close to 0 and not statistically significant (Panel A, col. 4). When we use the difference-in-differences specification (Panel A, col. 5, coefficient on After*Treat), we find that high school dropout men who entered the labor market in the fourth trimester of 1984 had a larger number of fixed-term contracts per year between 1990 and 2012 than men who entered the labor market in the third trimester of 1984. This effect is statistically significant: entering the labor market under a lax fixed term contract regulation increases the annual number of fixed-term contracts by 0.043 per year, which means $14.6 \%$ more fixed-term contracts per year.

When we analyze the impact of the reform not only on fixed-term contracts but on all nonpermanent contracts, we find stronger results. Thus, we find a positive and significant

\footnotetext{
${ }^{14}$ In order to capture a deeper understanding about instability in labor market careers, we include in this measure not only all fixed-term contracts but also all self-employment and special regimes' employment spells. The latter deals with employment in agriculture, fisheries, training programmes, etc. The average number of non-permanent contracts in our sample is 0.313 per year between 1990 and 2012, that is, about 7 employment spells in total between 1990 and 2012.
} 
impact of the reform on the number of non-permanent contracts held by male high-school dropouts (Table 4, Panel B, col. 2). Again, there is no effect of the reform on the number of non-permanent contracts held by high school graduates (Panel B, col. 4). The difference-indifferences specification (Panel B, col. 5) shows that the reform led to male high-school dropouts holding 0.052 (17.7\%) more non-permanent contracts per year between 1990 and 2012.

The fact that the impact of the reform is larger and more significant on all forms of nonpermanent work suggests that fixed-term contracts beget not only more fixed-term contracts but more precarious work (see footnote 15 above for the definition of nonpermanent work). Overall, these results show that men who entered the labor market under lax fixed term contracts regulation were more likely to hold non-stable employment contracts even years after their entry into the labor market.

Before examining long-run employment effects, we show the impact of the introduction of fixed term contracts on the initial labor market insertion of youth. Specifically, we investigate the impact of the reform on the probability of working before age 18 or before age 19. Graphically, the results are suggestive of a positive impact of the reform on the probability of finding a first job before age 18 (Figure 5) or 19 (Figure 6), especially if we exclude the transition cohorts born in the third and fourth trimester of 1968. We then use a regression on individual level data, with one observation per individual and using the cohort discontinuity design described by equation (1). Regression results (Table 5) ${ }^{15}$ show the policy change had a positive and significant impact on the probability of working before age 18 (when we dummy out the transition cohorts in col. 2) or 19 (col. 3 and 4). Those low educated native male workers who began working just after the 1984 reform are 9\% (col. 4) more likely to work before age 19. Thus, the reform may have facilitated the integration in the labor market for young people.

\section{Employment and earnings}

We now look at employment outcomes over the long-run. Since we expect the results to be concentrated in the first 10 years in the labor market, we first show graphs for outcomes in the first ten years of potential experience (Figure 7 and Figure 8). Employment and earnings trends were positive prior to the reform, with each cohort doing better than the previous cohort. In the trimester of the reform however, we see a large downward jump.

\footnotetext{
${ }^{15}$ Regressions also control for trimester of birth because there are important differences in the outcome depending on the trimester of birth (seasonality).
} 
Furthermore, the trend in both employment and wages becomes negative after the reform, with each cohort doing worse than the previous one. This negative post-reform trend may be due to the reform itself, given that the use of fixed-term contracts continued to grow after the reform (see Figure 2 and Figure 1). Thus, male high-school dropouts who entered the labor market under a lax fixed-term contract regime had lower employment and earnings during the first ten years of their careers.

Regressions in Table 6 confirm the negative impact of the reform on employment. Without controls, the reform is found to have decreased annual days of employment by 12 days. After controlling for macro factors (year effects) and potential labor market experience, the reform still has a negative and highly significant effect on yearly days worked: it reduces yearly days worked by 9.8 days (4.5\% of average yearly days worked in the first 10 years of potential experience by the pre-reform cohort born in the third trimester of 1968). For high school graduates, the impact of the reform on days worked is small and statistically insignificant (col. 3 and 4). In the difference-in-differences specification (2), where high school graduates serve as a control for high school dropouts, we find that the reform decreased the annual days worked by high-school dropouts by 17 days (col. 5). The fact that the difference-in-differences estimate is of the same order of magnitude as the estimates based on the cohort discontinuity alone is supportive of the assumption that our estimate of the impact of the reform is not driven by other changes in the labor market around the time of the reform.

Finally, we investigate the very long-run effects of the reform. In Table 6, column 6, we use all the years in our data and find that the reform decreased the yearly number of days worked by 6.5 days (2.4\% of average yearly days worked up to 2012 by the pre-reform cohort born in the third trimester of 1968). This effect corresponds to a total of 175.5 days of employment lost over 27 years by male high-school who entered the labor market under a lax fixed-term contract regulation. This negative employment effect is likely due to the fact that, as shown above, under a lax fixed term contract regulation, more non-permanent contracts are used, which likely leads to workers losing employment more often.

Apart from employment we also look at yearly earnings during the first ten years of potential labor market experience. Regressions in Table 7 show that men who entered the labor market under a laxer regulation of fixed term contracts accumulated lower earnings. ${ }^{16}$

\footnotetext{
${ }^{16}$ Among individuals with a fixed-term contracts some differences in wage growth patterns can also exist as there are diferent types of fixed-term contracts with diferent durations. In this line, the paper by Amuedo-
} 
The yearly earning loss is estimated to be $9 \%$ when we include year and experience fixed effects (second column of Table 7). Can this earnings loss be explained by the lower days of employment accumulated by the cohort entering the labor market during a lax fixed-term contract regulation (cohort born in the fourth trimester of 1968)? If we estimate the effect of the reform in percentage points, we get that the reform made affected workers to spend 4.5\% fewer days in employment. Given the estimated wage gap, we can see that about half of the large earnings loss experienced by the cohort entering the labor market after the reform could be explained by the fewer days of work accumulated by this cohort. The rest might be connected to the well-known wage gap between permanent and temporary workers observed in Spain since the beginning of the nineties (See Jimeno and Toharia, 1993). Furthermore, as documented in García Pérez and Rebollo (2005), Spanish workers suffer important wage losses (of about 11\%) due to involuntary job interruptions.

Next, we explore the impact of the reform on high-school graduates and find that the liberalization of fixed term contracts had no significant effect on log earnings (Table 7, col. 4) after controlling for year and experience fixed effects. The difference-in-differences estimate implies that the reform decreased the earnings of high school dropouts by $6.5 \%$ (col. 5), an estimate that is similar to our baseline estimate in col. 2. Finally, the very long term impact of the liberalization of fixed-term contracts on earnings is found to be negative and significant with a 7.5\% yearly earning loss (col. 6) over 27 years.

We have investigated the impact of the liberalization of fixed term contracts on employment and earnings by comparing the birth cohort that enters in the trimester before the reform with the birth cohort that enters in the trimester right after. However, as noted before based on the graphical analysis, each post-reform cohort was doing worse than the previous one in terms of days of work and earnings. Regressions confirm that the effect of the reform on the trend is significant and negative for both days of employment and earnings (see the coefficient on After*Trend in col. 2 in Table 6 and Table 7). The post reform-trend is negative (adding the coefficient on Trend and After*Trend). This evidence is thus consistent with the impact of the reform being more negative for younger cohorts entering the labor market after the reform, as the use of fixed-term contracts was ramping up.

Dorantes and Serrano-Padial (2007) shows that job-stayers with fixed-term contracts are more able to narrow their wage gap with respect to workers with permanent contracts (than job-movers with fixed-term contracts). 
Finally, we explore the timing of the impact of the liberalization of fixed-term contracts, to test our assumption that the impact of the reform is concentrated in the early years in the labor market. In Table 8, we estimate the impact of the reform separately for different levels of potential labor market experience: 0 to 9 years, 10 to 19 years, and more than 20 years. We find that the impact on both days worked and earnings is largest in the first ten years of labor market experience. The impact of the reform on yearly days worked is about $50 \%$ as large but still negative and significant for years of experience 10-19 and over 20 (col. 1). For earnings, the impact of the reform is more persistent: the negative impact of the reform is about $70 \%$ as large for years of experience 10-19 and over 20 (col.2). The liberalization of fixed term contracts had a negative impact on days worked and earnings in the first ten years of potential experience, and this negative effect was persistent if smaller at higher levels of labor market experience up to 27 years.

\section{Discussion and robustness checks}

\section{Discussion}

Our results differ from some of the findings in prior literature. In particular, our results differ from the ones in Aguirregabiria and Alonso-Borrego (2014) in the sense that they find an increase in job turn-over, as we do, but also an increase in total employment. This may be due to the fact that they analyze the firm's maximization problem for a sample quite different from the one we have. ${ }^{17}$ They find that these firms react to the reform by substituting permanent workers by temporary ones, all this process resulting in a 3.5\% increase in total employment but a null effect on productivity. They also find an increase in turnover what makes easier to exit from unemployment, especially for high-qualified workers who may be working more in equilibrium as the former paper finds. But, at the same time, this process makes it much easier for low-skilled workers to be unemployed, which results in a less stable career for this type of workers (the ones we analyze in this paper). Thus, in a similar flavor to the results from Aguirregabiria and Alonso-Borrego (2014), we do find an increase in employment at earlier ages, that we interpret as the reform facilitating the initial labor market insertion of young workers. However, we also find that the reform fostered a more unstable labor market career for low-skilled workers due to the increase in the number of non-permanent employment spells. Therefore, we go a

\footnotetext{
${ }^{17}$ They analyze the results of introducing temporary contracts with a sample of 2,356 Spanish manufacturing firms during the period 1982-1993. Hence, they focus on a group of firms larger than the average for the Spanish economy and where the typical worker is a medium-high qualified one with a permanent contract, both before and after the 1984 reform. As Table 1 shows, we have just $17.4 \%$ of workers in our sample working in manufacturing firms.
} 
step further from the current literature in providing evidence of the negative long-term effects of the introduction of temporary contracts.

\section{Robustness tests}

In our baseline results, we include 4 cohort-years (16 trimesters) before and 4 cohort-years after the reform. As a robustness test we reduce the bandwidth to 2 cohort years (8 trimesters) or 3 cohort years (12 trimesters). In both cases, the impact of the reform on days worked (col 1-2, Table 9) and earnings (col. 1-2 Table 10) is significant and quantitatively almost the same as in our baseline results. The negative impact of the liberalization of fixed-term contracts on employment and earnings is thus robust to the choice of bandwidth.

Linear trends are used in our baseline results. As a robustness test, we use second and third degree polynomials for the cohort trends. The negative impact of the reform on days worked is robust to the inclusion of these polynomial trends (col. 3-4, Table 9). For earnings, the impact of the reform is negative and significant with a quadratic trend (col. 3, Table 10), but loses significance with a cubic trend, though the point estimate is still negative (col. 4, Table 10) and not statistically significantly different from our baseline estimate. Overall, our results are thus generally robust to controlling for higher order polynomials.

In specification (1), we include all cohorts from the first trimester of 1965 to the fourth trimester of 1972. The reform was approved in August of 1984 but the law was not fully implemented until October 1984, so those born in the third trimester of 1968 may have been partially affected. At the same time, those born in the fourth trimester of 1968 may not have been fully affected if it took time for firms to adopt fixed-term contracts. Thus, we run the same model including dummies for these two transition cohorts (third and fourth trimester of 1968). The results of this model are reported in col. 5 Table 9 for days worked and in col. 5 Table 10 for earnings. The negative impact of the reform on days worked and earnings is thus robust to excluding transition cohorts from the estimation of the reform's impact.

Our baseline specification controls for years of potential experience, as is customary in wage regressions. However, one may be concerned that, to the extent that the post-reform cohort is one trimester younger than the pre-reform cohort, failing to control for this difference in potential experience may be biasing the results. Regression in Table 9 col. 6 and Table 10 col. 6 control for quarterly potential experience dummies. The negative 
impact of the reform on days worked and earnings is still highly significant, and is thus not driven by a failure to control for potential experience at the quarterly level.

One concern with our baseline estimates is that they could be biased by changes in the labor market that occurred in the same trimester as the reform. This concern is already made less acute by the fact that the difference-in-differences estimates show the same result as our baseline estimate. Furthermore, as we include the pre and post reform trends in our empirical model, we are only focusing on differences in long-term labor market outcomes between two trimester cohorts that enter the labor market only three months apart. Thus, we can expect the labor market conditions to be quite similar in a time span of only three months. Still, here, we explore the sensitivity of our results to trends in economic conditions. Indeed, prior to the reform, youth unemployment rate in Spain was very high and increasing (Figure 1). So one may worry that the worsening economic conditions are biasing the results. To address this concern we follow two alternative strategies. First, we split the sample into regions with average high (7 percentage points) and low (3.1 percentage points) growth in unemployment during the period 1982-1986. While the impact of the reform on days worked is negative in both low and high (Table 11) unemployment regions, the impact tends to be larger and more significant in low unemployment regions. This suggests that the negative impact of the reform on days worked was not driven by regions where unemployment was growing particularly rapidly. The second strategy we follow to account for the impact of labor market conditions is to include the unemployment rate of the trimester of labor market entry for each trimester cohort. Our main specification already controls for year fixed effects to account for macroeconomic conditions after entering the labor market. Thus, including the control for trimester unemployment rate accounts for differences in initial trimester economic conditions given the macroeconomic conditions in the current year (which are controlled for by the year fixed effects). We can see in Table 12 that the results including this additional variable remain negative and significant and the point estimates are somewhat larger (more negative) than our baseline results reported in Tables 6 and 7. Additionally, the unemployment rate coefficient is not significantly different from zero, consistent with the idea that labor conditions in the trimester before and after the introduction of the reform are not sufficiently different to turn the coefficient significant.

It has to be noted that this result is not comparable to the results found in the literature that study the long term effects of bad economic conditions at labor market entry. We are using a trimester cohort regression discontinuity approach in order to isolate the impact of the 
1984 reform by comparing only two trimester cohorts and controlling for differences in pre and post reform cohorts with the trends. On the other hand, the literature on long-term effects of economic conditions exploits the differences in unemployment rates at the time of labor market entry across all cohorts and regions. In fact, Garcia Perez and Vall Castelló (2015) use the same administrative data for Spain but follow the strategy in Oreopoulus et al. (2012) and report significant negative long-term employment and wage effects for highschool dropouts entering the labor market in bad economic conditions in Spain.

Finally, we perform placebo tests in which we simulate the policy to take place in a number of pre and post reform years (from 1966 to 1971). We use the specification from equation (1). The negative impact of the reform on days worked (appendix Figure 12) and earnings (appendix Figure 13) is largest for the true date. At the same time, the impact of the placebo reform is almost as negative though generally insignificant for dates after the reform. This can be explained by the fact that there is both a jump and a change in the cohort trend at the time of the reform, and linear trends are too coarse to capture such complex changes. To allow for a more local estimate of the cohort trend, we have performed these placebo tests with a narrower bandwidth of 2 cohort years instead of 4 cohort years. In this case, the impact of the reform on days worked is only negative and significant for the true date of the reform (Figure 9), and the placebo estimates for dates prior to or after the reform are close to zero. A similar picture emerges when the logarithm of yearly earnings is the outcome (Figure 10). These placebo tests reinforce our conclusion that the liberalization of fixed-term contracts use had a negative effect on the long-run employment and earnings outcomes for male high school dropouts.

\section{Conclusion}

In this paper, we have investigated the impact of entering the labor market under a lax regulation of fixed-term contracts on subsequent labor market outcomes. Using Spanish social security data, we found that the trimester-of-birth cohort of native male high school dropouts who entered the labor market under a lax regulation of fixed-term contracts experienced worse labor market outcomes than the cohort that just preceded them. Specifically, entering the labor market under a lax regulation of fixed-term contracts leads to $4.5 \%$ fewer days worked and a $9 \%$ reduction in earnings in the first ten years in the labor market. This is the case despite the fact that the reform likely increased the probability of working before age 19. The source of those negative effects on long-term outcomes is 
likely to be the larger probability of working under non-permanent contracts well after labor market entry, which also makes it more likely to be subject to the well known wage penalties due to unemployment and temporary work (see, for example, Jimeno and Toharia (1993), García Pérez and Rebollo (2005) or Fernández-Kranz et al. (2015)).

Hence, our findings suggest that, on balance, making fixed-term contracts more readily available reduced the welfare of low skilled workers. Even though these contracts seem to allow low skilled workers to secure a first job more rapidly, the long-run consequences are negative. Fixed-term contracts ultimately reduce the long-run employment and earnings prospects of low skilled workers. Far from being a stepping stone, fixed-term contracts are a stumbling block for the career of low skilled workers. 


\section{REFERENCES}

Aguirregabiria, V. and C. Alonso-Borrego (2014): Labor Contracts and Flexibility: Evidence from a Labor Market Reform in Spain. Economic Inquiry, Vol. 52, No. 2, April 2014, 930-957.

Amuedo-Dorantes, C. and R. Serrano-Padial (2007): Wage Growth Implications of FixedTerm Employment: An Analysis by Contract Duration and Job Mobility. Labour Economics, 14, 829-847.

Autor, D. and S. Houseman (2010): Do Temporary Help Jobs Improve Labor Market Outcomes for Low-Skilled Workers? Evidence from 'Work First'. American Economic Journal: Applied Economics, 2(3), July 2010, 96-128.

Autor D., Kerr W., Kugler A. (2007), “Do Employment Protections Reduce Productivity?

Evidence from U.S. States”, Economic Journal, vol. 117, issue 521.

Bentolila, S., Dolado, J., Cahuc P. and T. Le Barbanchon (2012): Two-Tier labour Markets in the Great Recession: France vs. Spain. Economic Journal, 122, F155-F187.

Blanchard, O. and A. Landier (2002): The Perverse Effects of Partial Labor Market Reform: Fixed-term Contracts in France. Economic Journal, 112, 214-244.

Blázquez Cuesta M. (2008): Low-wage Employment and Mobility in Spain, LABOUR, 22, 115-146.

Booth, S., Francesconi, M. and J. Frank (2002): Temporary Jobs: Stepping Stones or Dead Ends?. Economic Journal, 112, 183-213.

Borghans, Lex, Anne C. Gielen, and Erzo F. P. Luttmer. 2014. "Social Support Substitution and the Earnings Rebound: Evidence from a Regression Discontinuity in Disability Insurance Reform.” American Economic Journal: Economic Policy 6 (4): 34-70. doi:10.1257/pol.6.4.34.

Cingano F., Leonardi M., Messina J. and Pica G. (2015), "Employment Protection Legislation, Capital Investment and Access to Credit: Evidence from Italy", Economic Journal, DOI: 10.1111/ecoj.12212.

D’Addio, A.C. and M. Rosholm (2005): Exits from Temporary Jobs in Europe: A Competing-Risk Analysis. Labour Economics, 12, 449-468.

Costain, J., Jimeno, J and C. Thomas (2010): Employment fluctuations in a dual labour market, Bank of Spain Working Paper No. 1013.

Dolado, J.J., Garcia-Serrano, C. and J.F. Jimeno (2002): Drawing Lessons from the Boom of Temporary Jobs in Spain. Economic Journal, 112, 270-295.

Dolado, J.J., Jansen M., Felgueroso F., Fuentes A. and A.Wölfl (2013): Youth Labour Market Performance in Spain and its Determinants. A Micro-Level Perspective, OECD Econ. DepartmentWorking Paper No. 1039.

Fernández-Kranz, D., Paul, M., and N. Rodriguez-Planas (2015): Part-Time Status, FixedTerm Contracts, and the Returns to Experience. Oxford Bulletin of Economics and Statistics,77-4, 512-541. 
García Pérez J.I. and Y. Rebollo (2005): Wage changes through job mobility: does unemployment mean a penalty in Europe?- Labour Economics, Vol 12, Issue 4, pp. 531556.

García Pérez J.I. and Y. Rebollo (2009): The use of permanent contracts across Spanish regions: do regional wage subsides work? . Investigaciones Económicas, XXXIII(1), 97130.

Garcia-Perez, J.I. and F. Muñoz-Bullón, (2011): Transitions into Permanent Employment in Spain: An Empirical Analysis for Young Workers. British Journal of Industrial Relations, 49, 103-143.

Garcia-Perez, J.I. and J. Vall Castelló (2015): Youth Unemployment in Spain: More Issues than just High Unemployment. In No country for young people? Youth labour market problems in Europe, edited by Juan J. Dolado, CEPR Press, A VoxEU.org book, pp.117128.

Güell, M. and Petrongolo, B. (2007): How Binding are Legal Limits? Transitions from Temporary to Permanent Work in Spain. Labour Economics, 14, 153-183.

Ichino, A., Mealli, F. and Nannicini, T. (2008): From temporary help jobs to permanent employment: what can we learn from matching estimators and their sensitivity?. Journal of Applied. Econometrics., 23: 305-327. doi: 10.1002/jae.998.

Jimeno, J. F. and Toharia L. (1993): The effects of Fixed-term Employment on Wages: Theory and Evidence from Spain, Investigaciones Económicas, 27, 475-494.

Kahn, L. (2010): The Long-Term Labor Market Consequences of Graduating from College in a Bad Economy. Labour Economics, Vol. 17, No. 2, April, 2010.

Kugler, A., Jimeno, J.F., and V. Hernanz (2005): Employment Consequences of Restrictive Employment Policies: Evidence from Spanish Labor Market Reforms. Mimeo.

Mateos, B., and C. Sebastián (1988): Los Programas de Fomento y la Evolución del Empleo. In Estudios sobre participación activa, empleo y paro en España, Estudios de FEDEA number 7, pp. 411-444.

Documento elaborado para la Comisión de Expertos para el estudio del desempleo en España. Mimeo.

McCrary, Justin. 2008. "Manipulation of the Running Variable in the Regression Discontinuity Design: A Density Test." Journal of Econometrics, The regression discontinuity design: Theory and applications, 142 (2): 698-714. doi:10.1016/j.jeconom.2007.05.005.

Moulton, G. J. (2011): Great Depression of Wages: An Investigation of the Impact of Entering the Labor Market during the Great Depression using a Regression Discontinuity Approach, working paper.

Nagore, A., and A. Van Soest (2014): Unemployment Transitions to Stable and Unstable Jobs Before and During the Crisis. IZA Discussion Paper No. 8121.

OECD (1987): Employment Outlook.

OECD (1993): Employment Outlook. 
OECD (2006), Employment Outlook, chapter 7

Oreopoulos, P.,Von Wachter, T., and A. Heisz (2012). The Short and Long Term Career Effects of Graduating in a Recession. American Economic Journal: Applied Economics, Vol. 4(1), 1-29.

Rebollo, Y. (2011): Landing a Permanent Contract in Spain: Do Job Interruptions and Employer Diversification Matter?. The Manchester School, 79 (6), 1197-1236.

Zijl, M., Van Den Berg, G. and A. Heyma (2004): Stepping Stones for the Unemployed: The Effect of Temporary Jobs on the Duration until Regular Work. IZA Discussion Paper 1241. 
Figure 1. Unemployment rate in Spain for workers with less than 25 years old; share of temporary contracts for men aged 15-24 in Spain and average share of temporary contracts for men aged 15-24 in the OECD.

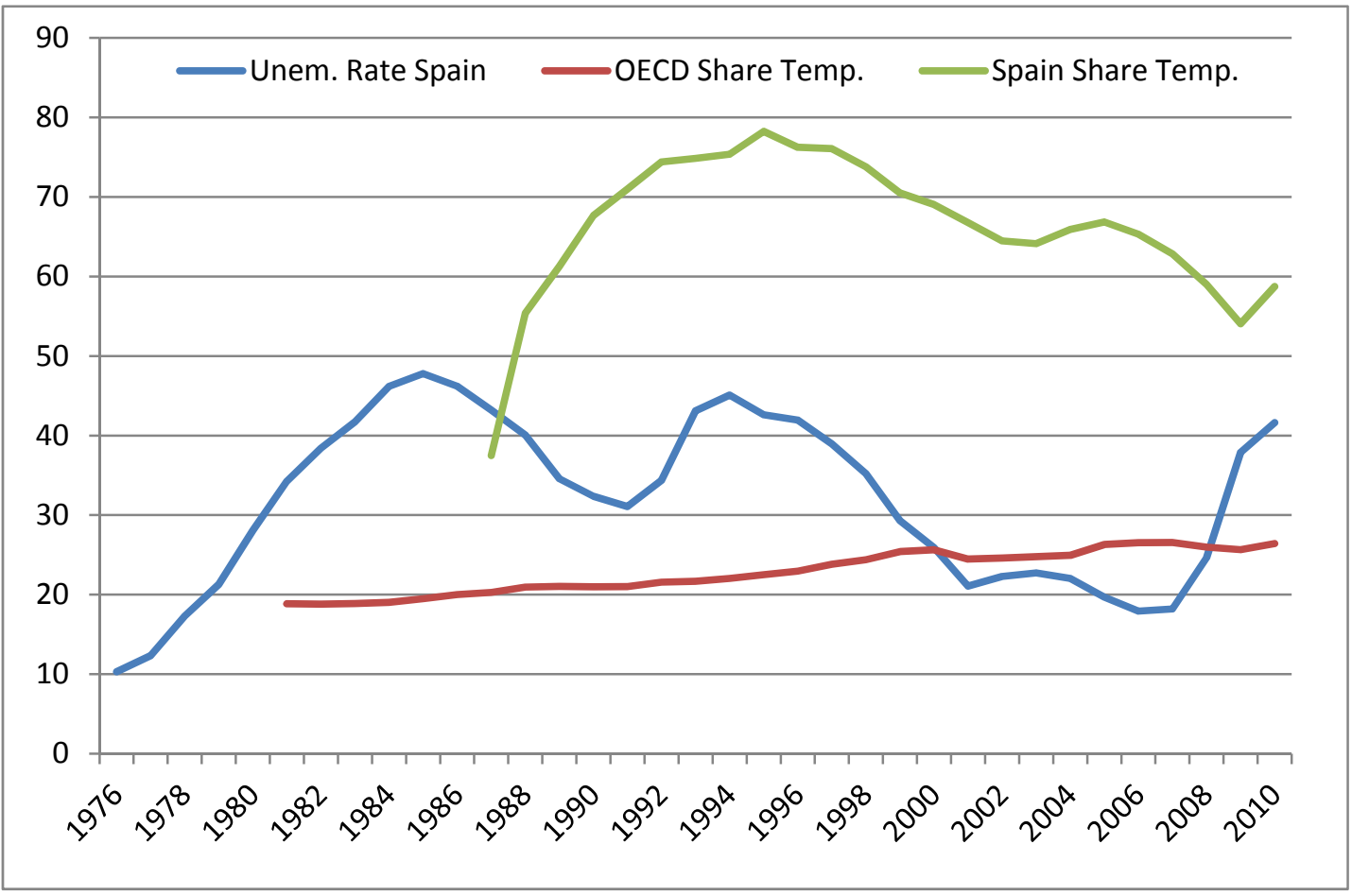

Source: Own elaboration from data from the OECD and the Spanish National Institute of Statistics (EPA). 
Figure 2. Total number of temporary contracts and total number of employees in non-agricultural private sectors.

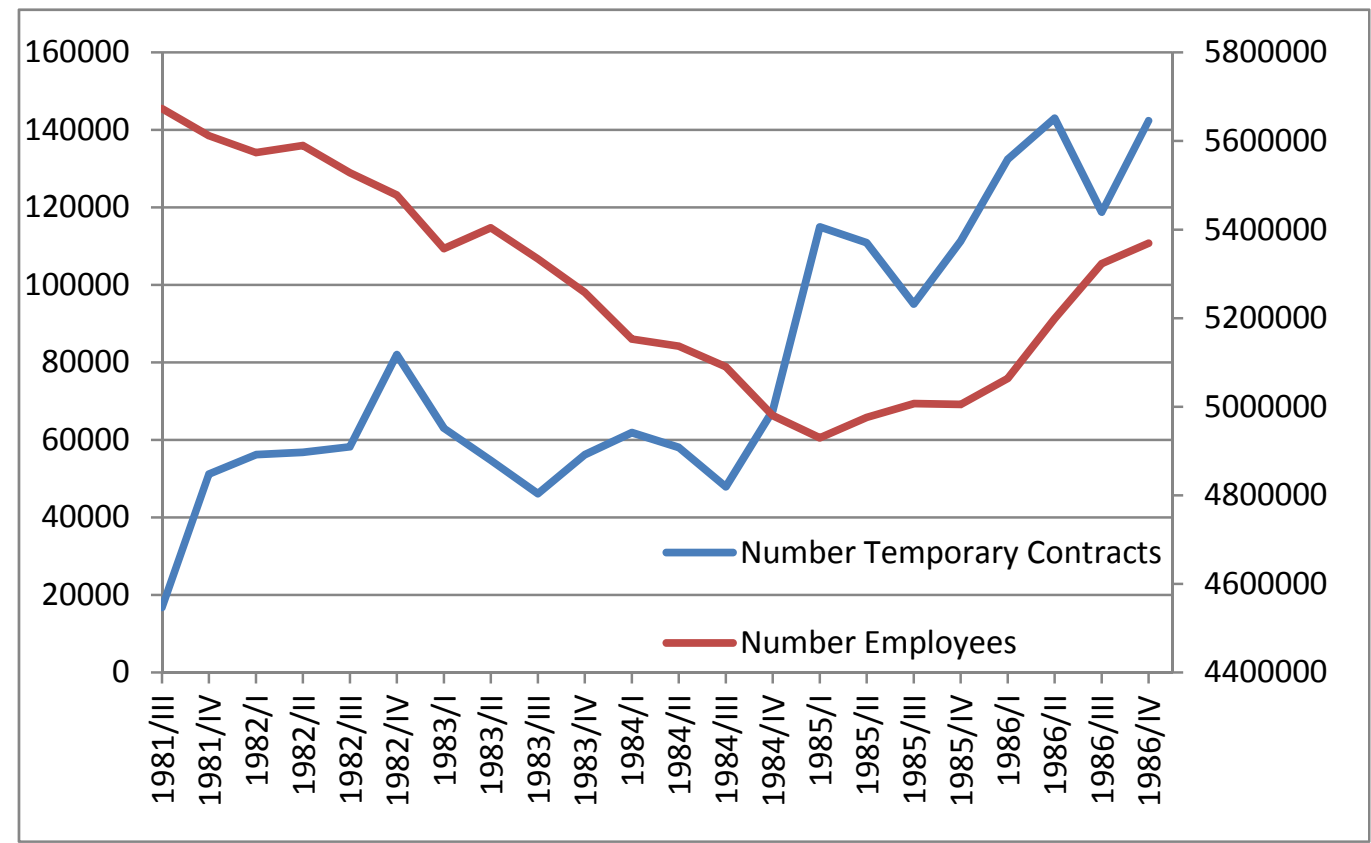

Source: Own elaboration from data from the Spanish National Institute of Statistics (EPA). 
Figure 3. Number of apprenticeship contracts and percentage of apprenticeship contracts with respect to employees in non-agricultural private sectors aged between 16 and 19 years old.

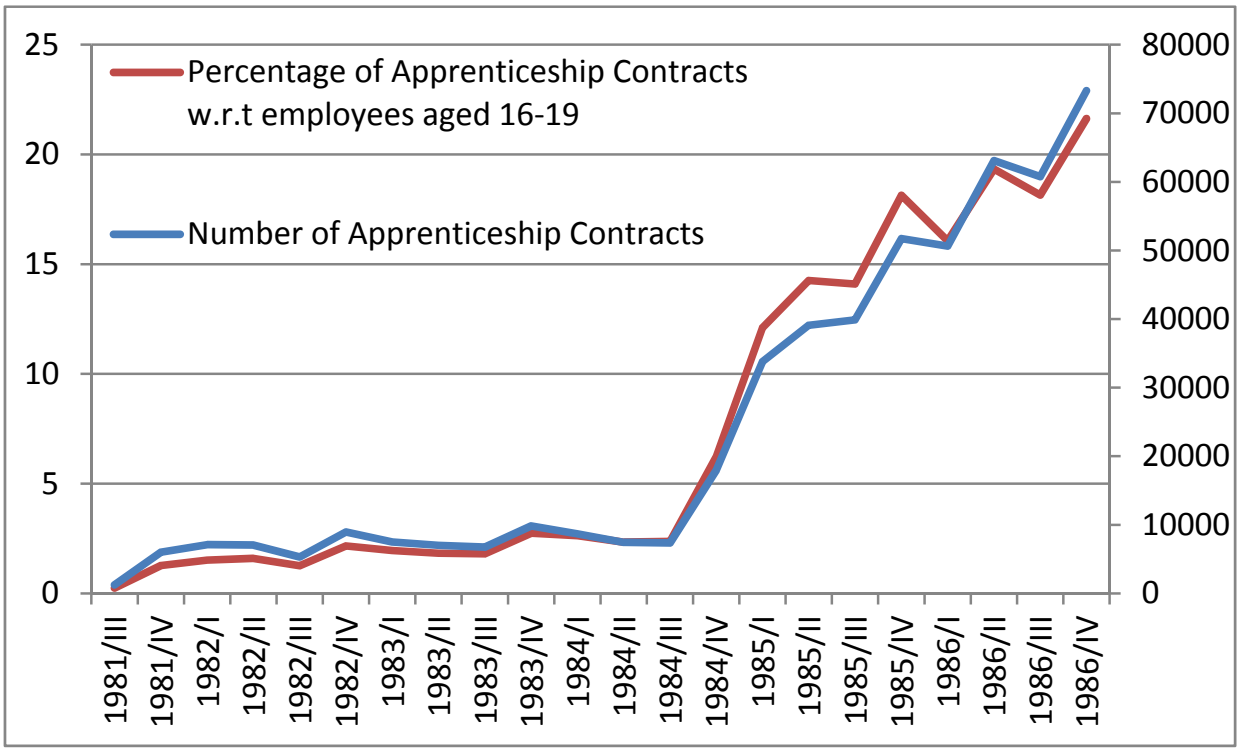

Source: Own elaboration from data from the Spanish National Institute of Statistics (EPA). 
Table 1. Descriptive Statistics ${ }^{18}$.

\begin{tabular}{|c|c|c|c|c|}
\hline & \multicolumn{2}{|c|}{$\begin{array}{c}\text { HIGH SCHOOL } \\
\text { DROPOUT }\end{array}$} & \multicolumn{2}{|c|}{$\begin{array}{l}\text { HIGH SCHOOL } \\
\text { GRADUATE }\end{array}$} \\
\hline & Obs & Mean & Obs & Mean \\
\hline Unempl. Rate Region at LM Entry & 24.934 & 19.05 & 68.611 & 18.70 \\
\hline \multicolumn{5}{|l|}{ REGION AT LM ENTRY } \\
\hline Andalucia & 6.409 & 25.70 & 13.469 & 19.63 \\
\hline Aragon & 417 & 1.67 & 1.897 & 2.76 \\
\hline Asturias & 476 & 1.91 & 1.558 & 2.27 \\
\hline Baleares & 534 & 2.14 & 1.832 & 2.67 \\
\hline Canarias & 1.707 & 6.85 & 3.214 & 4.68 \\
\hline Cantabria & 298 & 1.20 & 882 & 1.29 \\
\hline Cast. Leon & 1.403 & 5.63 & 3.189 & 4.65 \\
\hline Cast. Mancha & 1.270 & 5.09 & 3.970 & 5.79 \\
\hline Catalunya & 3.304 & 13.25 & 10.485 & 15.28 \\
\hline Valencia & 2.841 & 11.39 & 7.214 & 10.51 \\
\hline Extremadura & 1.022 & 4.10 & 2.097 & 3.06 \\
\hline Galicia & 1.637 & 6.57 & 4.093 & 5.97 \\
\hline Madrid & 1.911 & 7.66 & 7.698 & 11.22 \\
\hline Murcia & 800 & 3.21 & 2.203 & 3.21 \\
\hline Navarra & 172 & 0.69 & 955 & 1.39 \\
\hline Pais Vasco & 624 & 2.50 & 3.402 & 4.96 \\
\hline Rioja & 109 & 0.44 & 453 & 0.66 \\
\hline \multicolumn{5}{|l|}{ SECTOR OF FIRST JOB } \\
\hline High Tech. Manufacturing & 1.585 & 6.36 & 5.735 & 8.40 \\
\hline Low Tech. Manufacturing & 2.862 & 11.48 & 8.415 & 12.32 \\
\hline High Tech. Services & 552 & 2.21 & 2.682 & 3.93 \\
\hline Finance & 47 & 0.19 & 201 & 0.29 \\
\hline Health and Education & 234 & 0.94 & 798 & 1.17 \\
\hline Trade & 3.553 & 14.25 & 12.792 & 18.73 \\
\hline Hotels and Catering services & 2.301 & 9.23 & 7.089 & 10.38 \\
\hline Other low tech. Activities & 986 & 3.95 & 3.382 & 4.95 \\
\hline Agriculture & 4.643 & 18.62 & 7.137 & 10.45 \\
\hline Mining and Energy & 124 & 0.50 & 343 & 0.50 \\
\hline Construction & 4.608 & 18.48 & 10.105 & 14.80 \\
\hline Public Administration & 1.001 & 4.01 & 2.550 & 3.73 \\
\hline Real State & 97 & 0.39 & 360 & 0.53 \\
\hline Temporary Help Agencies & 55 & 0.22 & 282 & 0.41 \\
\hline Missing & 2.286 & 9.17 & 6.416 & 9.40 \\
\hline
\end{tabular}

Source: Muestra Continua de Vidas Laborales (MCVL).

${ }^{18}$ See table 12 in the appendix for a more detailed explanation of each sector. 
Table 2. Distribution of cohorts in the sample

\begin{tabular}{l|cc|cc}
\hline & HIGH SCHOOL & \multicolumn{2}{c}{$\begin{array}{c}\text { HIGH SCHOOL } \\
\text { GRADUATE }\end{array}$} \\
\hline COHORT & Obs & Mean & Obs & Mean \\
1962 & & & & \\
1963 & 2.265 & 9.08 & 4.556 & 6.67 \\
1964 & 2.285 & 9.16 & 4.641 & 6.80 \\
1965 & 2.289 & 9.18 & 4.957 & 7.26 \\
1966 & 2.009 & 8.06 & 4.709 & 6.90 \\
1967 & 2.104 & 8.44 & 4.809 & 7.04 \\
1968 & 1.988 & 7.97 & 4.765 & 6.98 \\
1969 & 1.792 & 7.19 & 4.846 & 7.10 \\
1970 & 1.653 & 6.63 & 4.818 & 7.06 \\
1971 & 1.618 & 6.49 & 4.835 & 7.08 \\
1972 & 1.495 & 6.00 & 5.173 & 7.58 \\
1973 & 1.440 & 5.78 & 5.005 & 7.33 \\
1974 & 1.401 & 5.62 & 4.956 & 7.26 \\
1975 & 1.271 & 5.10 & 5.042 & 7.38 \\
\hline
\end{tabular}

Source: Muestra Continua de Vidas Laborales (MCVL). 
Figure 4. Total number of men in our sample for each birth cohort and share of males who are high-school dropouts for each cohort.

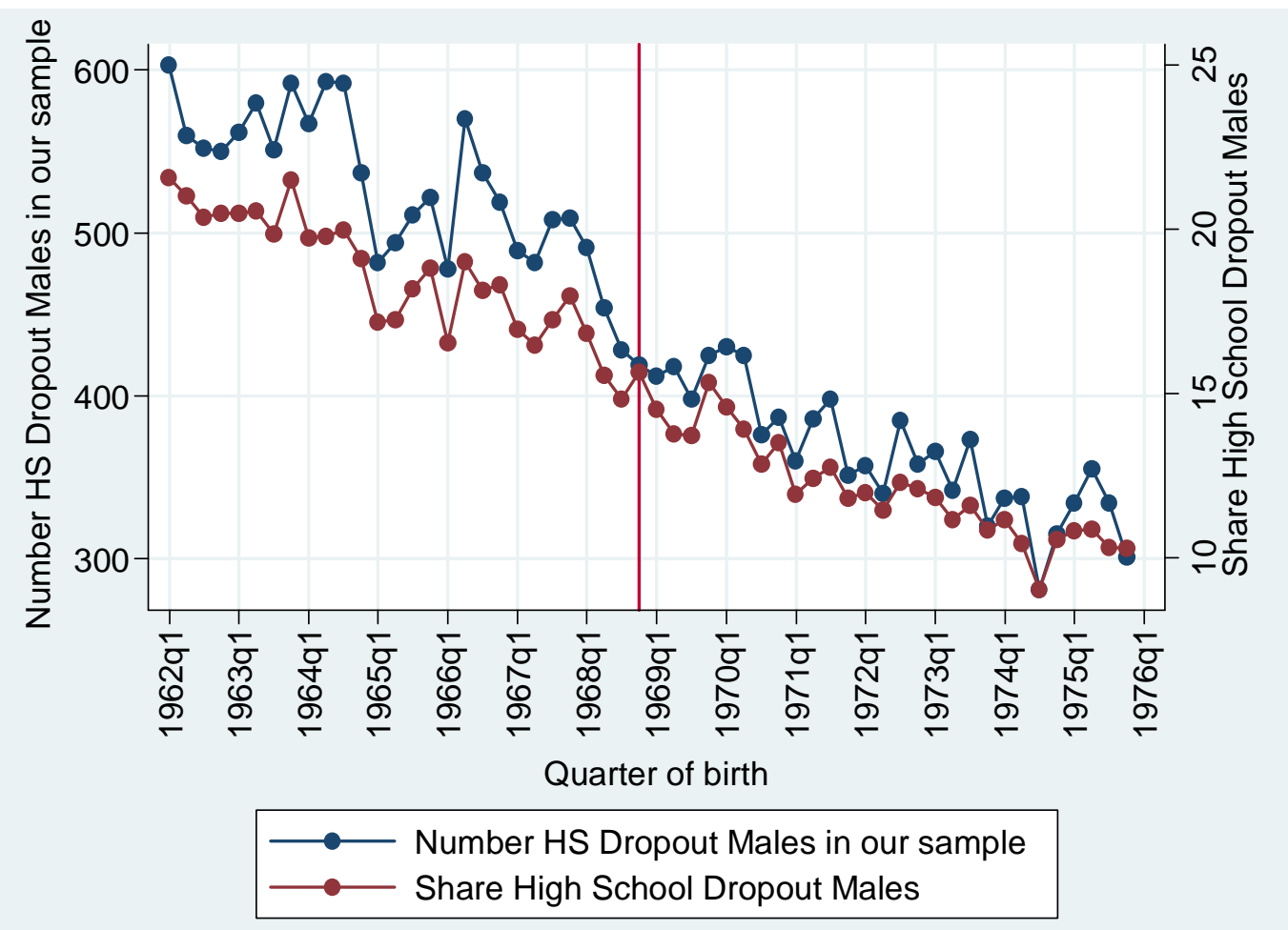

Source: Muestra Continua de Vidas Laborales (MCVL). 
Table 3. Probability of being a high school dropout.

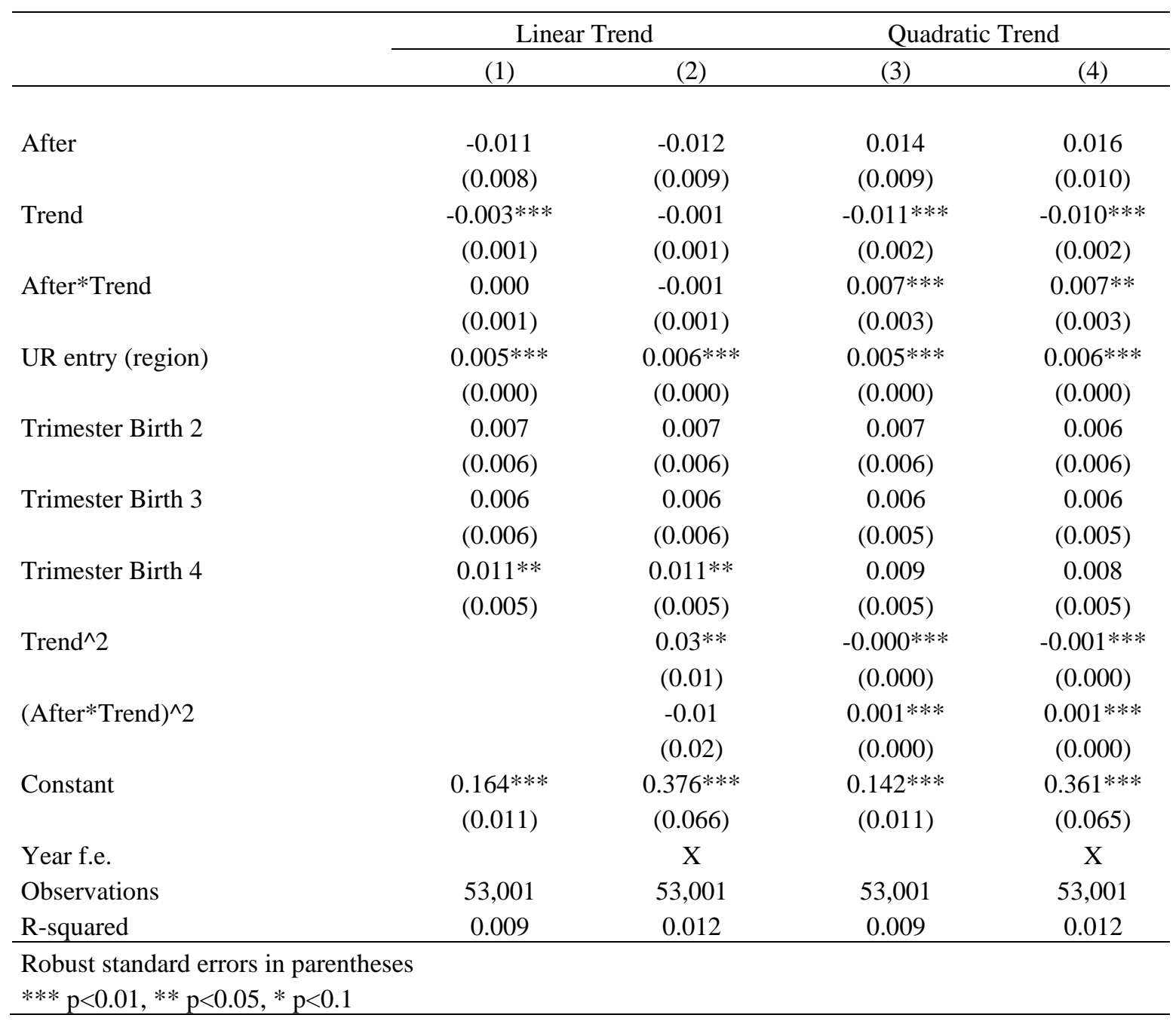

Source: Muestra Continua de Vidas Laborales (MCVL) Sample of Native Males who are High School dropouts (born between 1965 and 1972 and start working before age 20) or High School graduates (born between 19621969 and start working before age 22). 
Table 4. Number of temporary and non-permanent contracts per year

\begin{tabular}{|c|c|c|c|c|c|}
\hline & \multicolumn{5}{|c|}{ Since 1990 up to 2012} \\
\hline & \multicolumn{2}{|c|}{ High school dropouts } & \multicolumn{2}{|c|}{ High school graduates } & \multirow{2}{*}{$\frac{\mathrm{DiD}}{(5)}$} \\
\hline & (1) & $(2)$ & (3) & (4) & \\
\hline \multicolumn{6}{|c|}{$\begin{array}{l}\text { Panel A: Temporary } \\
\text { contracts }\end{array}$} \\
\hline \multirow[t]{2}{*}{ After } & 0.043 & 0.043 & -0.006 & -0.007 & -0.006 \\
\hline & $(0.027)$ & $(0.028)$ & $(0.011)$ & $(0.011)$ & $(0.011)$ \\
\hline \multirow[t]{2}{*}{ Trend } & 0.003 & 0.002 & $0.005^{* * *}$ & 0.003 & 0.003 \\
\hline & $(0.002)$ & $(0.008)$ & $(0.001)$ & $(0.002)$ & $(0.002)$ \\
\hline \multirow[t]{2}{*}{ After*Trend } & 0.005 & 0.005 & 0.002 & 0.002 & $0.003^{*}$ \\
\hline & $(0.003)$ & $(0.003)$ & $(0.001)$ & $(0.001)$ & $(0.001)$ \\
\hline \multirow[t]{2}{*}{ After*Treat } & & & & & $0.043 * *$ \\
\hline & & & & & $(0.018)$ \\
\hline \multirow[t]{2}{*}{ Treat } & & & & & $0.099 * * *$ \\
\hline & & & & & $(0.013)$ \\
\hline \multicolumn{2}{|l|}{ Year f.e. } & $\mathrm{X}$ & & $\mathrm{X}$ & $\mathrm{X}$ \\
\hline \multicolumn{2}{|l|}{ Potential exp f.e. } & $\mathrm{X}$ & & $\mathrm{X}$ & $\mathrm{X}$ \\
\hline Observations & 912 & 912 & 1,008 & 1,008 & 1,92 \\
\hline R-squared & 0.056 & 0.900 & 0.059 & 0.945 & 0.907 \\
\hline \multicolumn{6}{|c|}{$\begin{array}{l}\text { Panel B: Non-permanent } \\
\text { contracts }\end{array}$} \\
\hline \multirow[t]{2}{*}{ After } & $0.060 * *$ & $0.059 * *$ & -0.007 & -0.003 & -0.001 \\
\hline & $(0.023)$ & $(0.024)$ & $(0.026)$ & $(0.030)$ & $(0.026)$ \\
\hline \multirow[t]{2}{*}{ Trend } & $0.003^{*}$ & 0.001 & $0.007 * * *$ & $0.009 *$ & $0.008^{*}$ \\
\hline & $(0.002)$ & $(0.006)$ & $(0.002)$ & $(0.005)$ & $(0.004)$ \\
\hline \multirow[t]{2}{*}{ After*Trend } & $0.006 * *$ & $0.006 * *$ & -0.001 & -0.001 & 0.001 \\
\hline & $(0.003)$ & $(0.003)$ & $(0.002)$ & $(0.002)$ & $(0.002)$ \\
\hline \multirow[t]{2}{*}{ After*Treat } & & & & & $0.052 * *$ \\
\hline & & & & & $(0.023)$ \\
\hline \multirow[t]{2}{*}{ Treat } & & & & & $0.108 * * *$ \\
\hline & & & & & $(0.021)$ \\
\hline Year f.e. & & $X$ & & $\mathrm{X}$ & X \\
\hline \multicolumn{2}{|l|}{ Potential exp f.e. } & $\mathrm{X}$ & & $\mathrm{X}$ & $\mathrm{X}$ \\
\hline Observations & 912 & 912 & 1,008 & 1,008 & 1,92 \\
\hline R-squared & 0.061 & 0.887 & 0.057 & 0.905 & 0.880 \\
\hline \multicolumn{6}{|c|}{ Robust standard errors clustered by cohort in parentheses } \\
\hline \multicolumn{6}{|c|}{$* * * \mathrm{p}<0.01, * * \mathrm{p}<0.05, * \mathrm{p}<0.1$} \\
\hline
\end{tabular}

Source: Muestra Continua de Vidas Laborales (MCVL) Sample of Native Males who are High School dropouts (born between 1965 and 1972 and start working before age 20) or High School graduates (born between 19621969 and start working before age 22). 
Figure 5. Plot of beta coefficients for the probability of working before age 18 for high-school dropouts.

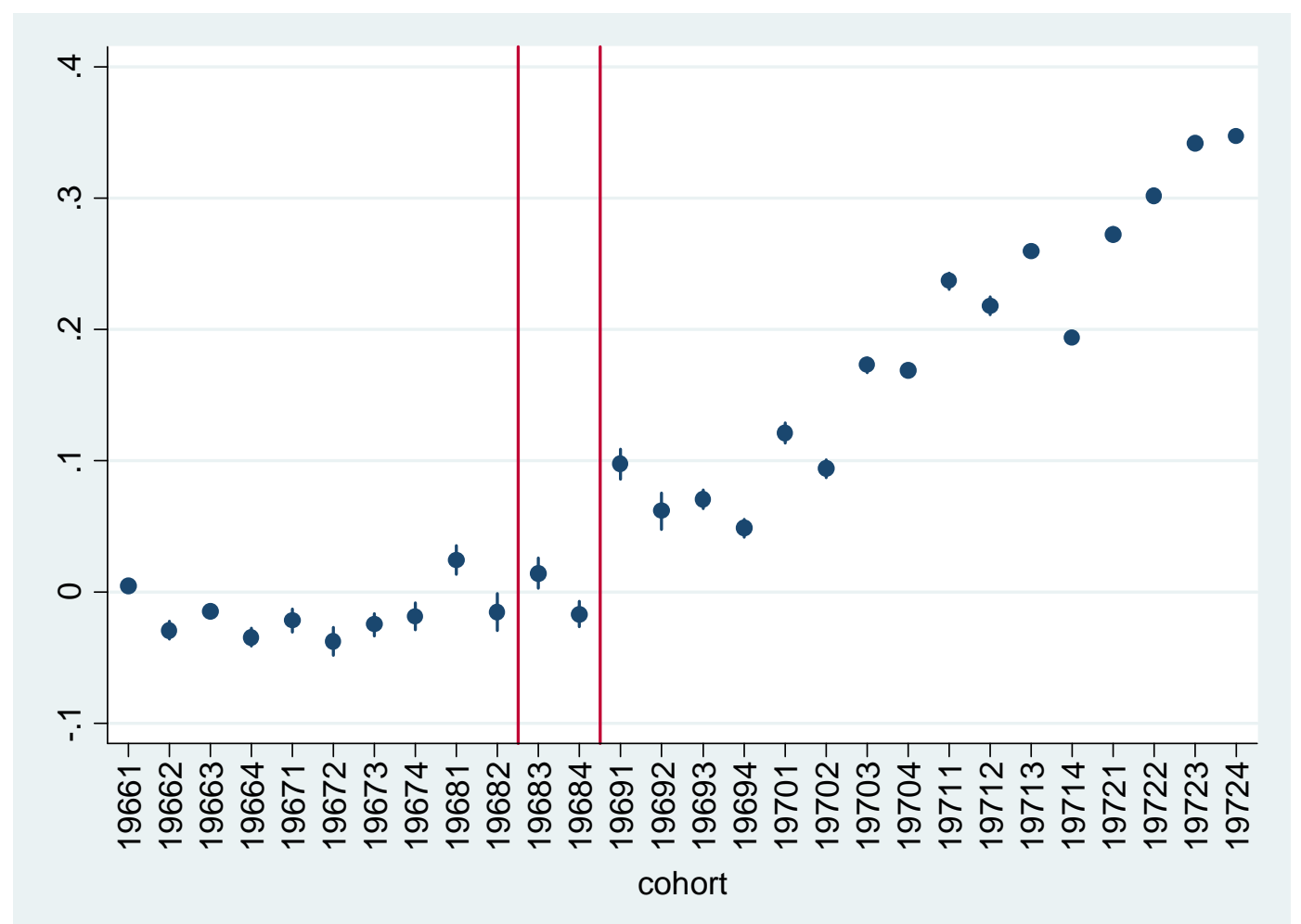

Note: The coefficients are from a regression of the probability of having the first job at age 18 or before with dummies for cohorts, dummies for the trimester of birth and the unemployment rate of the region at the trimester of labor market entry.

Source: Muestra Continua de Vidas Laborales (MCVL). 
Figure 6. Plot of beta coefficients for the probability of working before age 19 for high-school dropouts.

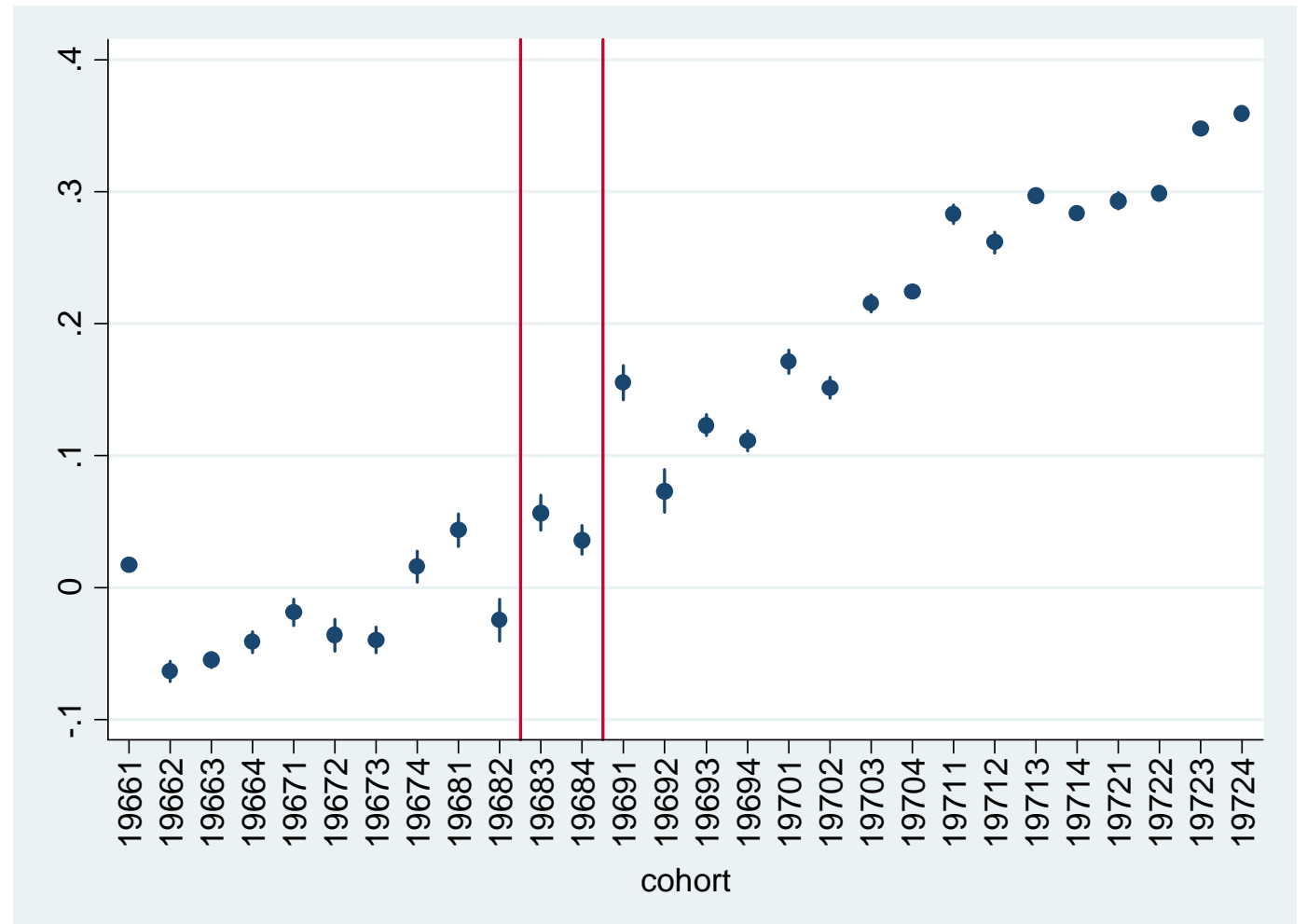

Note: The coefficients are from a regression of the probability of having the first job at age 19 or before with dummies for cohorts, dummies for the trimester of birth and the unemployment rate of the region at the trimester of labor market entry. 
Table 5. Probability of working before age 18/19, individual-level data.

\begin{tabular}{|c|c|c|c|c|}
\hline & \multicolumn{2}{|c|}{ Before 18} & \multicolumn{2}{|c|}{ Before 19} \\
\hline & $(1)$ & $(2)$ & (3) & $(4)$ \\
\hline \multirow[t]{2}{*}{ After } & 0.02 & $0.03^{*}$ & $0.06 * * *$ & $0.09 * * *$ \\
\hline & $(0.01)$ & $(0.02)$ & $(0.02)$ & $(0.02)$ \\
\hline \multirow[t]{2}{*}{ Trend } & -0.00 & -0.00 & 0.00 & 0.00 \\
\hline & $(0.00)$ & $(0.00)$ & $(0.00)$ & $(0.00)$ \\
\hline \multirow[t]{2}{*}{ After*Trend } & $0.02 * * *$ & $0.02 * * *$ & $0.02 * * *$ & $0.02 * * *$ \\
\hline & $(0.00)$ & $(0.00)$ & $(0.00)$ & $(0.00)$ \\
\hline \multirow[t]{2}{*}{ UR entry (region) } & $-0.01 * * *$ & $-0.01 * * *$ & -0.00 & -0.00 \\
\hline & $(0.00)$ & $(0.00)$ & $(0.00)$ & $(0.00)$ \\
\hline \multirow[t]{2}{*}{ Trimester Birth 1} & $0.11 * * *$ & $0.11 * * *$ & $0.13 * * *$ & $0.12 * * *$ \\
\hline & $(0.01)$ & $(0.01)$ & $(0.01)$ & $(0.01)$ \\
\hline \multirow[t]{2}{*}{ Trimester Birth 2} & $0.09 * * *$ & $0.09 * * *$ & $0.10 * * *$ & $0.10 * * *$ \\
\hline & $(0.01)$ & $(0.01)$ & $(0.01)$ & $(0.01)$ \\
\hline \multirow[t]{2}{*}{ Trimester Birth 3} & $0.05^{* * *}$ & $0.05 * * *$ & $0.04 * * *$ & $0.03 * *$ \\
\hline & $(0.01)$ & $(0.01)$ & $(0.01)$ & $(0.01)$ \\
\hline \multirow[t]{2}{*}{ Cohort 1968.3} & & $0.03 * *$ & & $0.07 * * *$ \\
\hline & & $(0.01)$ & & $(0.02)$ \\
\hline \multirow[t]{2}{*}{ Cohort 1968.4} & & -0.01 & & $-0.04 * *$ \\
\hline & & $(0.02)$ & & $(0.02)$ \\
\hline \multirow[t]{2}{*}{ Constant } & $0.35 * * *$ & $0.34 * * *$ & $0.44 * * *$ & $0.42 * * *$ \\
\hline & $(0.06)$ & $(0.06)$ & $(0.07)$ & $(0.07)$ \\
\hline Observations & 14,071 & 14,071 & 14,071 & 14,071 \\
\hline R-squared & 0.08 & 0.08 & 0.07 & 0.07 \\
\hline \multicolumn{5}{|c|}{$\begin{array}{l}\text { Robust standard errors in parentheses } \\
*^{* *} \mathrm{p}<0.01,{ }^{* *} \mathrm{p}<0.05,{ }^{*} \mathrm{p}<0.1\end{array}$} \\
\hline
\end{tabular}

Source: Muestra Continua de Vidas Laborales (MCVL) Sample of Native Males who are High School dropouts (born between 1965 and 1972 and start working before age 20) or High School graduates (born between 19621969 and start working before age 22). 
Figure 7. Annual number of days worked in the first ten years of potential labor market experience: high-school dropouts

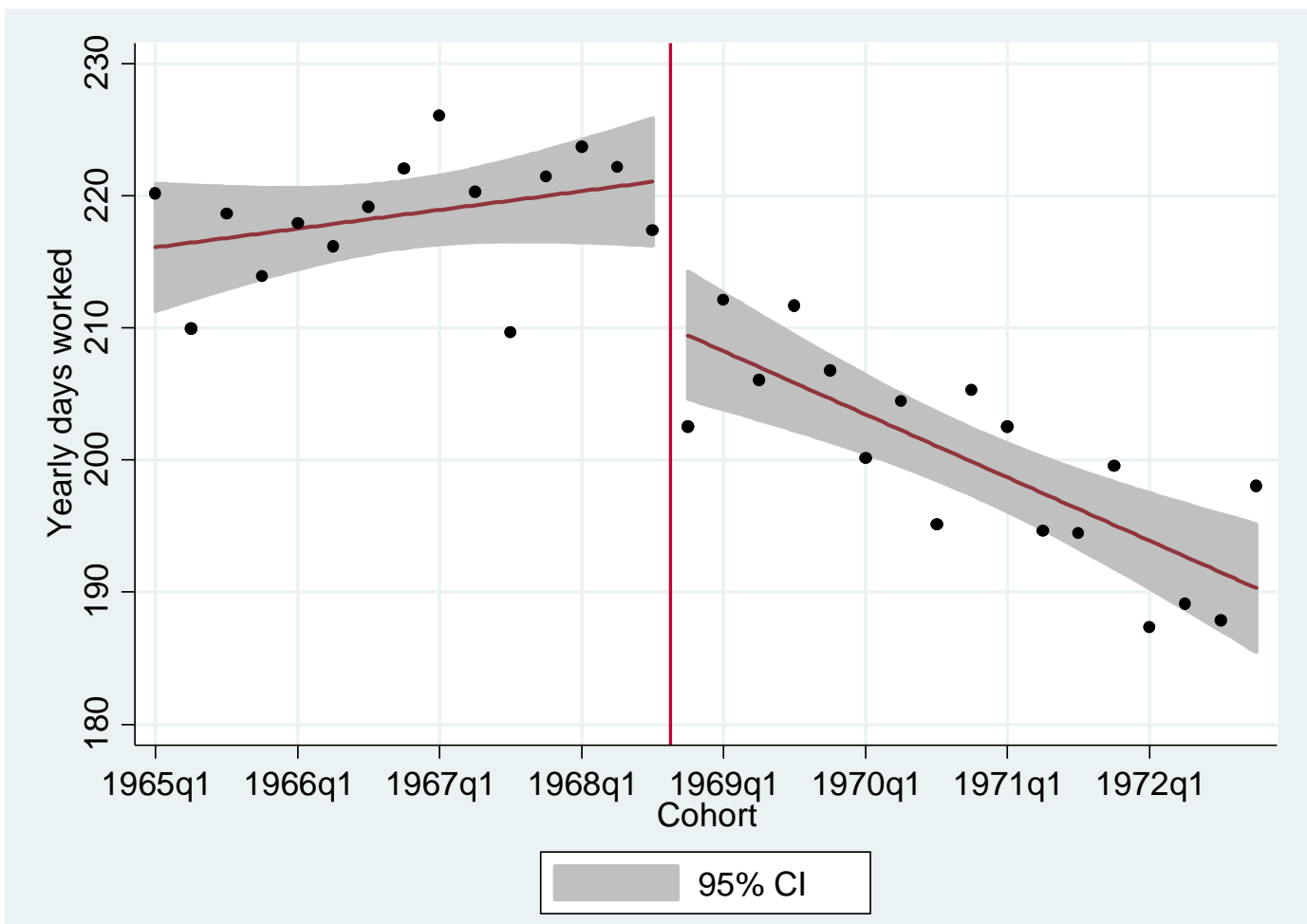

Source: Muestra Continua de Vidas Laborales (MCVL). 
Figure 8. Logarithm of yearly earnings in the first 10 years of labor market experience: high-school dropouts.

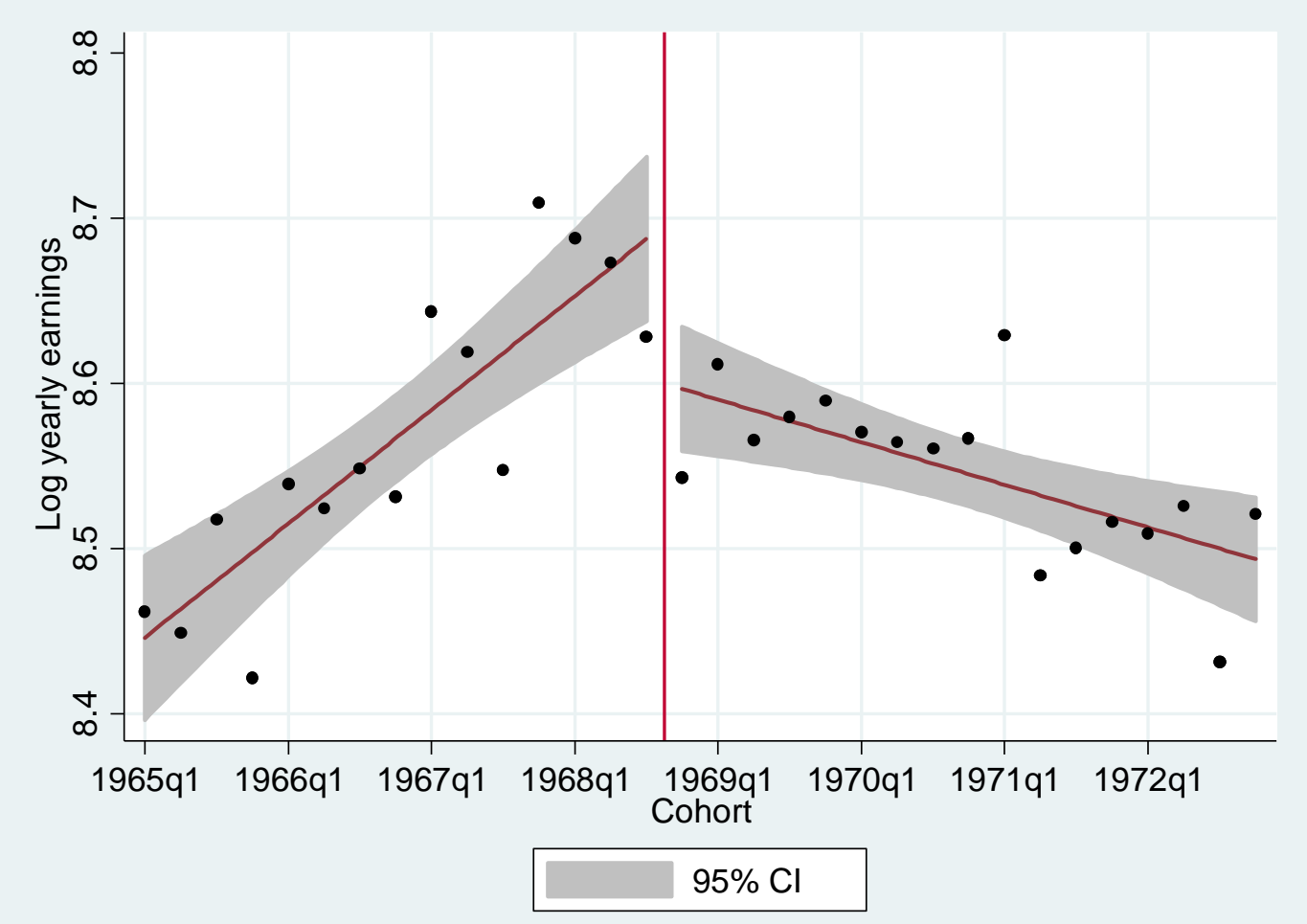

Source: Muestra Continua de Vidas Laborales (MCVL). 


\begin{tabular}{|c|c|c|c|c|c|c|}
\hline & \multicolumn{5}{|c|}{ First 10 years of potential experience } & \multirow{3}{*}{$\begin{array}{l}\text { Up to } 2012 \\
\begin{array}{l}\text { High school } \\
\text { dropouts }\end{array} \\
(6)\end{array}$} \\
\hline & \multicolumn{2}{|c|}{ High school dropouts } & \multicolumn{2}{|c|}{ High school graduates } & \multirow{2}{*}{$\begin{array}{c}\mathrm{DiD} \\
(5)\end{array}$} & \\
\hline & $(1)$ & $(2)$ & (3) & (4) & & \\
\hline \multirow[t]{2}{*}{ After } & $-11.916 * * *$ & $-9.829 * * *$ & 1.852 & 0.816 & 2.838 & $-6.503 * * *$ \\
\hline & (3.194) & $(3.376)$ & (2.375) & $(3.223)$ & $(2.529)$ & $(2.272)$ \\
\hline \multirow[t]{2}{*}{ Trend } & 0.373 & -0.571 & $0.421 *$ & $-3.272 * * *$ & $-2.529 * * *$ & 0.048 \\
\hline & $(0.245)$ & $(0.826)$ & $(0.208)$ & $(0.485)$ & $(0.385)$ & $(0.641)$ \\
\hline \multirow[t]{2}{*}{ After*Trend } & $-1.602^{* * *}$ & $-1.604 * * *$ & $-0.897 * * *$ & -0.274 & $-0.526 * *$ & $-0.751 * * *$ \\
\hline & $(0.356)$ & $(0.360)$ & $(0.256)$ & $(0.319)$ & $(0.241)$ & $(0.267)$ \\
\hline \multirow{2}{*}{ After*Treat } & & & & & $-17.073 * * *$ & \\
\hline & & & & & (2.166) & \\
\hline \multirow[t]{2}{*}{ Treat } & & & & & $-28.503 * * *$ & \\
\hline & & & & & (1.893) & \\
\hline Year f.e. & & $x$ & & $x$ & x & $x$ \\
\hline Potential exp f.e. & & $x$ & & $x$ & $x$ & $x$ \\
\hline Observations & 352 & 352 & 416 & 416 & 768 & 912 \\
\hline R-squared & 0.060 & 0.849 & 0.002 & 0.889 & 0.809 & 0.938 \\
\hline
\end{tabular}

Robust standard errors clustered by cohort in parentheses

$* * * \mathrm{p}<0.01, * * \mathrm{p}<0.05, * \mathrm{p}<0.1$

Source: Muestra Continua de Vidas Laborales (MCVL) Sample of Native Males who are High School dropouts (born between 1965 and 1972 and start working before age 20) or High School graduates (born between 19621969 and start working before age 22). 


\begin{tabular}{|c|c|c|c|c|c|c|}
\hline & \multicolumn{5}{|c|}{ First 10 years of potential experience } & \multirow{3}{*}{$\begin{array}{l}\text { Up to } 2012 \\
\text { High school } \\
\text { dropouts } \\
(6)\end{array}$} \\
\hline & \multicolumn{2}{|c|}{ High school dropouts } & \multicolumn{2}{|c|}{ High school graduates } & \multirow{2}{*}{$\begin{array}{l}\text { DiD } \\
(5) \\
\end{array}$} & \\
\hline & $(1)$ & $(2)$ & $(3)$ & $(4)$ & & \\
\hline After & $\begin{array}{c}-0.106 * * * \\
(0.030)\end{array}$ & $\begin{array}{c}-0.089 * * * \\
(0.028)\end{array}$ & $\begin{array}{c}0.057^{* * *} \\
(0.016)\end{array}$ & $\begin{array}{c}0.007 \\
(0.026)\end{array}$ & $\begin{array}{c}0.006 \\
(0.019)\end{array}$ & $\begin{array}{c}-0.075 * * * \\
(0.020)\end{array}$ \\
\hline Trend & $\begin{array}{c}0.017^{* * *} \\
(0.003)\end{array}$ & $\begin{array}{l}-0.008 \\
(0.008)\end{array}$ & $\begin{array}{l}-0.001 \\
(0.001)\end{array}$ & $\begin{array}{c}-0.040 * * * \\
(0.004)\end{array}$ & $\begin{array}{c}-0.033^{* * *} \\
(0.003)\end{array}$ & $\begin{array}{c}0.001 \\
(0.006)\end{array}$ \\
\hline After*Trend & $\begin{array}{c}-0.024 * * * \\
(0.003)\end{array}$ & $\begin{array}{c}-0.020 * * * \\
(0.003)\end{array}$ & $\begin{array}{c}0.001 \\
(0.002)\end{array}$ & $\begin{array}{c}0.003 \\
(0.003)\end{array}$ & $\begin{array}{l}-0.002 \\
(0.002)\end{array}$ & $\begin{array}{c}-0.012 * * * \\
(0.002)\end{array}$ \\
\hline After*Treat & & & & & $\begin{array}{c}-0.065^{* *} \\
(0.025)\end{array}$ & \\
\hline Treat & & & & & $\begin{array}{c}-0.368 * * * \\
(0.023)\end{array}$ & \\
\hline Year f.e. & & $x$ & & $x$ & $\mathrm{X}$ & $\mathrm{X}$ \\
\hline Potential exp f.e. & & $x$ & & $x$ & $x$ & $x$ \\
\hline Observations & 352 & 352 & 404 & 404 & 756 & 912 \\
\hline R-squared & 0.032 & 0.907 & 0.008 & 0.921 & 0.893 & 0.974 \\
\hline
\end{tabular}

Robust standard errors clustered by cohort in parentheses

*** $\mathrm{p}<0.01, * * \mathrm{p}<0.05, * \mathrm{p}<0.1$

Source: Muestra Continua de Vidas Laborales (MCVL) Sample of Native Males who are High School dropouts (born between 1965 and 1972 and start working before age 20) or High School graduates (born between 19621969 and start working before age 22). 
Table 8. Interactions of the effect of the reform with potential experience dummies. High-school dropouts.

\begin{tabular}{lcc}
\hline & Days Worked & Log.Earnings \\
\cline { 2 - 3 } & & $(1)$ \\
\hline & 0.033 & 0.000 \\
Trend & $(0.641)$ & $(0.005)$ \\
& $-0.726^{* *}$ & $-0.012^{* * *}$ \\
After*Trend & $(0.267)$ & $(0.002)$ \\
& $-9.976^{* * *}$ & $-0.094^{* * *}$ \\
After*PotExp0_9 & $(3.522)$ & $(0.029)$ \\
& $-4.493^{*}$ & $-0.067^{* *}$ \\
After*PotExp10_19 & $(2.574)$ & $(0.025)$ \\
& $-5.512^{*}$ & $-0.063^{* *}$ \\
After*PotExp20+ & $(2.767)$ & $(0.023)$ \\
& $259.672^{* * *}$ & $8.195^{* * *}$ \\
Constant & $(85.511)$ & $(0.630)$ \\
& $\mathrm{X}$ & $\mathrm{X}$ \\
Year f.e. & $\mathrm{X}$ & $\mathrm{X}$ \\
Potential exp f.e. & 912 & 912 \\
Observations & 0.939 & 0.974 \\
R-squared & & \\
\hline Robust standard errors in parentheses & & \\
$* * *$ p $<0.01, * * \mathrm{p}<0.05, * \mathrm{p}<0.1$ & & \\
\hline
\end{tabular}

Source: Muestra Continua de Vidas Laborales (MCVL) Sample of Native Males who are High School dropouts (born between 1965 and 1972 and start working before age 20) or High School graduates (born between 19621969 and start working before age 22). 
Table 9. Robustness checks. Number of days worked per year, high-school dropouts.

\begin{tabular}{|c|c|c|c|c|c|c|}
\hline & \multicolumn{5}{|c|}{ First 10 years of potential experience } & \multirow{3}{*}{$\begin{array}{c}\text { Controlling } \\
\text { Trimesters } \\
\text { Pot. Exp. }\end{array}$} \\
\hline & \multicolumn{2}{|c|}{ Reducing Bandwidth } & \multicolumn{2}{|c|}{ Polynomial Trends } & \multirow{2}{*}{$\begin{array}{l}\text { Dummies } \\
\text { for } \\
\text { transition } \\
\text { cohorts }\end{array}$} & \\
\hline & 8 Trimest & 12 Trimest & $\begin{array}{c}\text { 2nd } \\
\text { Degree }\end{array}$ & $\begin{array}{c}\text { 3rd } \\
\text { Degree }\end{array}$ & & \\
\hline After & $\begin{array}{c}-10.789 * * * \\
(3.255)\end{array}$ & $\begin{array}{c}-11.391 * * * \\
(3.129)\end{array}$ & $\begin{array}{c}-10.784^{* *} \\
(4.486)\end{array}$ & $\begin{array}{c}-11.214^{*} \\
(5.782)\end{array}$ & $\begin{array}{c}-8.693^{* *} \\
(3.650)\end{array}$ & $\begin{array}{c}-10.726^{* * * *} \\
(3.480)\end{array}$ \\
\hline Trend & $\begin{array}{c}-2.077^{*} \\
(1.037)\end{array}$ & $\begin{array}{l}-1.274 \\
(0.794)\end{array}$ & $\begin{array}{c}-0.502 \\
(1.333)\end{array}$ & $\begin{array}{l}-2.255 \\
(3.280)\end{array}$ & $\begin{array}{l}-0.054 \\
(0.848)\end{array}$ & $\begin{array}{c}0.857^{* * *} \\
(0.203)\end{array}$ \\
\hline After*Trend & $\begin{array}{l}-0.805 \\
(0.833)\end{array}$ & $\begin{array}{c}-1.199 * * * \\
(0.388)\end{array}$ & $\begin{array}{l}-1.271 \\
(1.409)\end{array}$ & $\begin{array}{c}3.121 \\
(3.917)\end{array}$ & $\begin{array}{c}-1.883^{* * *} \\
(0.381)\end{array}$ & $\begin{array}{c}-1.558^{* * *} \\
(0.365)\end{array}$ \\
\hline Trend $\wedge 2$ & & & $\begin{array}{c}0.001 \\
(0.067)\end{array}$ & $\begin{array}{l}-0.261 \\
(0.483)\end{array}$ & & \\
\hline After*Trend $\wedge 2$ & & & $\begin{array}{l}-0.024 \\
(0.094)\end{array}$ & $\begin{array}{l}-0.185 \\
(0.574)\end{array}$ & & \\
\hline Trend $\wedge 3$ & & & & $\begin{array}{l}-0.011 \\
(0.019)\end{array}$ & & \\
\hline After*Trend^${ }^{\wedge} 3$ & & & & $\begin{array}{c}0.029 \\
(0.023)\end{array}$ & & \\
\hline Year f.e. & $\mathrm{X}$ & $\mathrm{X}$ & $\mathrm{X}$ & $\mathrm{X}$ & $\mathrm{X}$ & $\mathrm{X}$ \\
\hline Potent exp. f.e. & $\mathrm{X}$ & $\mathrm{X}$ & $\mathrm{X}$ & $\mathrm{X}$ & $\mathrm{X}$ & $\mathrm{X}$ \\
\hline Observations & 176 & 264 & 352 & 352 & 352 & 352 \\
\hline R-squared & 0.864 & 0.855 & 0.849 & 0.850 & 0.850 & 0.867 \\
\hline
\end{tabular}

Robust standard errors clustered by cohort in parentheses

*** $\mathrm{p}<0.01,{ }^{* *} \mathrm{p}<0.05,{ }^{*} \mathrm{p}<0.1$

Source: Muestra Continua de Vidas Laborales (MCVL) Sample of Native Males who are High School dropouts (born between 1965 and 1972 and start working before age 20) or High School graduates (born between 19621969 and start working before age 22). 
Table 10. Robustness checks. Logarithm of yearly earnings, high-school dropouts.

\begin{tabular}{|c|c|c|c|c|c|c|}
\hline & \multicolumn{5}{|c|}{ First 10 years of potential experience } & \multirow{3}{*}{$\begin{array}{c}\text { Controlling } \\
\text { Trimesters } \\
\text { Pot. Exp. }\end{array}$} \\
\hline & \multicolumn{2}{|c|}{ Reducing Bandwidth } & \multicolumn{2}{|c|}{ Polynomial Trends } & \multirow{2}{*}{$\begin{array}{l}\text { Dummies } \\
\text { for } \\
\text { transition } \\
\text { cohorts }\end{array}$} & \\
\hline & 8 Trimest & 12 Trimest & 2nd Degree & $\begin{array}{c}\text { 3rd } \\
\text { Degree }\end{array}$ & & \\
\hline After & $\begin{array}{c}-0.086^{* * *} \\
(0.027)\end{array}$ & $\begin{array}{c}-0.095^{* * *} \\
(0.029)\end{array}$ & $\begin{array}{c}-0.093^{* *} \\
(0.034)\end{array}$ & $\begin{array}{l}-0.064 \\
(0.042)\end{array}$ & $\begin{array}{c}-0.096 * * * \\
(0.029)\end{array}$ & $\begin{array}{c}-0.097 * * * \\
(0.026)\end{array}$ \\
\hline Trend & $\begin{array}{l}-0.011 \\
(0.008)\end{array}$ & $\begin{array}{l}-0.011 \\
(0.010)\end{array}$ & $\begin{array}{l}-0.012 \\
(0.010)\end{array}$ & $\begin{array}{l}-0.041 \\
(0.029)\end{array}$ & $\begin{array}{c}-0.004 \\
(0.008)\end{array}$ & $\begin{array}{c}0.014^{* * *} \\
(0.002)\end{array}$ \\
\hline After*Trend & $\begin{array}{l}-0.007 \\
(0.006)\end{array}$ & $\begin{array}{c}-0.016^{* * *} \\
(0.004)\end{array}$ & $\begin{array}{l}-0.008 \\
(0.010)\end{array}$ & $\begin{array}{c}0.034 \\
(0.033)\end{array}$ & $\begin{array}{c}-0.022 * * * \\
(0.003)\end{array}$ & $\begin{array}{c}-0.019 * * * \\
(0.003)\end{array}$ \\
\hline Trend $\wedge 2$ & & & $\begin{array}{l}-0.000 \\
(0.000)\end{array}$ & $\begin{array}{l}-0.005 \\
(0.005)\end{array}$ & & \\
\hline After*Trend ${ }^{\wedge} 2$ & & & $\begin{array}{l}-0.000 \\
(0.001)\end{array}$ & $\begin{array}{c}0.002 \\
(0.005)\end{array}$ & & \\
\hline Trend^3 & & & & $\begin{array}{l}-0.000 \\
(0.000)\end{array}$ & & \\
\hline After*Trend^3 & & & & $\begin{array}{c}0.000 \\
(0.000)\end{array}$ & & \\
\hline Year f.e. & $\mathrm{X}$ & $\mathrm{X}$ & $\mathrm{X}$ & $\mathrm{X}$ & $\mathrm{X}$ & $\mathrm{X}$ \\
\hline Potential exp f.e. & $\mathrm{X}$ & $\mathrm{X}$ & $\mathrm{X}$ & $\mathrm{X}$ & $\mathrm{X}$ & $\mathrm{X}$ \\
\hline Observations & 176 & 264 & 352 & 352 & 352 & 352 \\
\hline R-squared & 0.921 & 0.912 & 0.907 & 0.908 & 0.908 & 0.934 \\
\hline
\end{tabular}

Robust standard errors clustered by cohort in parentheses *** $\mathrm{p}<0.01,{ }^{* *} \mathrm{p}<0.05, * \mathrm{p}<0.1$

Source: Muestra Continua de Vidas Laborales (MCVL) Sample of Native Males who are High School dropouts (born between 1965 and 1972 and start working before age 20) or High School graduates (born between 19621969 and start working before age 22). 
Table 11 . Number of days worked per year in regions with low and high unemployment rate growth in the 1980s.

\begin{tabular}{|c|c|c|c|c|c|c|}
\hline & \multicolumn{6}{|c|}{ First 10 years of potential experience } \\
\hline & \multicolumn{4}{|c|}{ Low UR growth } & \multicolumn{2}{|c|}{ High UR growth } \\
\hline & HS dropouts & HS graduates & $\mathrm{DiD}$ & HS dropouts & HS graduates & DiD \\
\hline & $(1)$ & $(2)$ & (3) & $(4)$ & $(5)$ & (6) \\
\hline After & $\begin{array}{c}-16.647 * * * \\
(5.037)\end{array}$ & $\begin{array}{c}0.206 \\
(4.369)\end{array}$ & $\begin{array}{c}0.888 \\
(3.219)\end{array}$ & $\begin{array}{l}-5.491 \\
(5.205)\end{array}$ & $\begin{array}{c}1.296 \\
(3.197)\end{array}$ & $\begin{array}{c}4.197 \\
(2.882)\end{array}$ \\
\hline Trend & $\begin{array}{c}0.587 \\
(1.011)\end{array}$ & $\begin{array}{c}-4.528 * * * \\
(0.669)\end{array}$ & $\begin{array}{c}-3.312^{* * *} \\
(0.528)\end{array}$ & $\begin{array}{l}-1.388 \\
(1.192)\end{array}$ & $\begin{array}{c}-2.526^{* * *} \\
(0.466)\end{array}$ & $\begin{array}{c}-2.074 * * * \\
(0.397)\end{array}$ \\
\hline After*Trend & $\begin{array}{c}-2.115^{* * *} \\
(0.626)\end{array}$ & $\begin{array}{l}-0.568 \\
(0.428)\end{array}$ & $\begin{array}{c}-0.872^{* *} \\
(0.329)\end{array}$ & $\begin{array}{c}-1.411^{* *} \\
(0.614)\end{array}$ & $\begin{array}{l}-0.097 \\
(0.310)\end{array}$ & $\begin{array}{l}-0.343 \\
(0.289)\end{array}$ \\
\hline After*Treat & & & $\begin{array}{c}-17.094^{* * *} \\
(3.391)\end{array}$ & & & $\begin{array}{c}-17.223^{* * *} \\
(3.066)\end{array}$ \\
\hline Treat & & & $\begin{array}{c}-34.466 * * * \\
(2.553)\end{array}$ & & & $\begin{array}{c}-25.041^{* * *} \\
(2.727)\end{array}$ \\
\hline Year f.e. & $\mathrm{X}$ & $\mathrm{X}$ & $\mathrm{X}$ & $\mathrm{X}$ & $\mathrm{X}$ & $\mathrm{X}$ \\
\hline Potential exp f.e. & $\mathrm{X}$ & $\mathrm{X}$ & $\mathrm{X}$ & $\mathrm{X}$ & $\mathrm{X}$ & $\mathrm{X}$ \\
\hline Observations & 352 & 416 & 768 & 352 & 416 & 768 \\
\hline R-squared & 0.813 & 0.880 & 0.790 & 0.821 & 0.883 & 0.802 \\
\hline
\end{tabular}

Note: Regions with low average unemployment rate growth (3.1 percentage points) in 1982-1986 were: Baleares, Catalunya, Valencia, Murcia \& Castilla La Mancha.

Source: Muestra Continua de Vidas Laborales (MCVL) Sample of Native Males who are High School dropouts (born between 1965 and 1972 and start working before age 20) or High School graduates (born between 19621969 and start working before age 22). 
Table 12. Number of days worked per year and logarithm of yearly wages for high school dropouts after controlling for the unemployment rate of the trimester of labor market entry.

\begin{tabular}{|c|c|c|c|c|}
\hline & \multicolumn{4}{|c|}{ First 10 years of potential experience } \\
\hline & \multicolumn{2}{|c|}{ Number of days worked } & \multicolumn{2}{|c|}{ Logarithm yearly wages } \\
\hline & $(1)$ & (2) & (3) & (4) \\
\hline \multirow[t]{2}{*}{ After } & $-15.028^{* * *}$ & $-14.704 * * *$ & $-0.156 * * *$ & $-0.116 * * *$ \\
\hline & (4.462) & $(5.070)$ & $(0.036)$ & $(0.035)$ \\
\hline \multirow{2}{*}{ Trend } & -0.528 & -1.486 & 0.003 & -0.013 \\
\hline & (1.279) & $(1.385)$ & (0.011) & $(0.012)$ \\
\hline \multirow{2}{*}{ After*Trend } & -0.363 & 0.412 & -0.004 & -0.008 \\
\hline & (1.684) & $(2.002)$ & (0.014) & (0.016) \\
\hline \multirow{2}{*}{ LM entry UR } & 1.913 & 3.116 & 0.030 & 0.018 \\
\hline & (2.580) & (2.966) & $(0.021)$ & $(0.023)$ \\
\hline Year f.e. & & $\mathrm{x}$ & & $\mathrm{x}$ \\
\hline Potential exp f.e. & & $\mathrm{x}$ & & $\mathrm{x}$ \\
\hline Observations & 352 & 352 & 352 & 352 \\
\hline R-squared & 0.060 & 0.849 & 0.033 & 0.907 \\
\hline
\end{tabular}

Robust standard errors clustered by cohort in parentheses *** $\mathrm{p}<0.01, * * \mathrm{p}<0.05, * \mathrm{p}<0.1$

Source: Muestra Continua de Vidas Laborales (MCVL) Sample of Native Males who are High School dropouts (born between 1965 and 1972 and start working before age 20). 
Figure 9. Number of days worked per year: placebo test, 2 cohort-years bandwidth

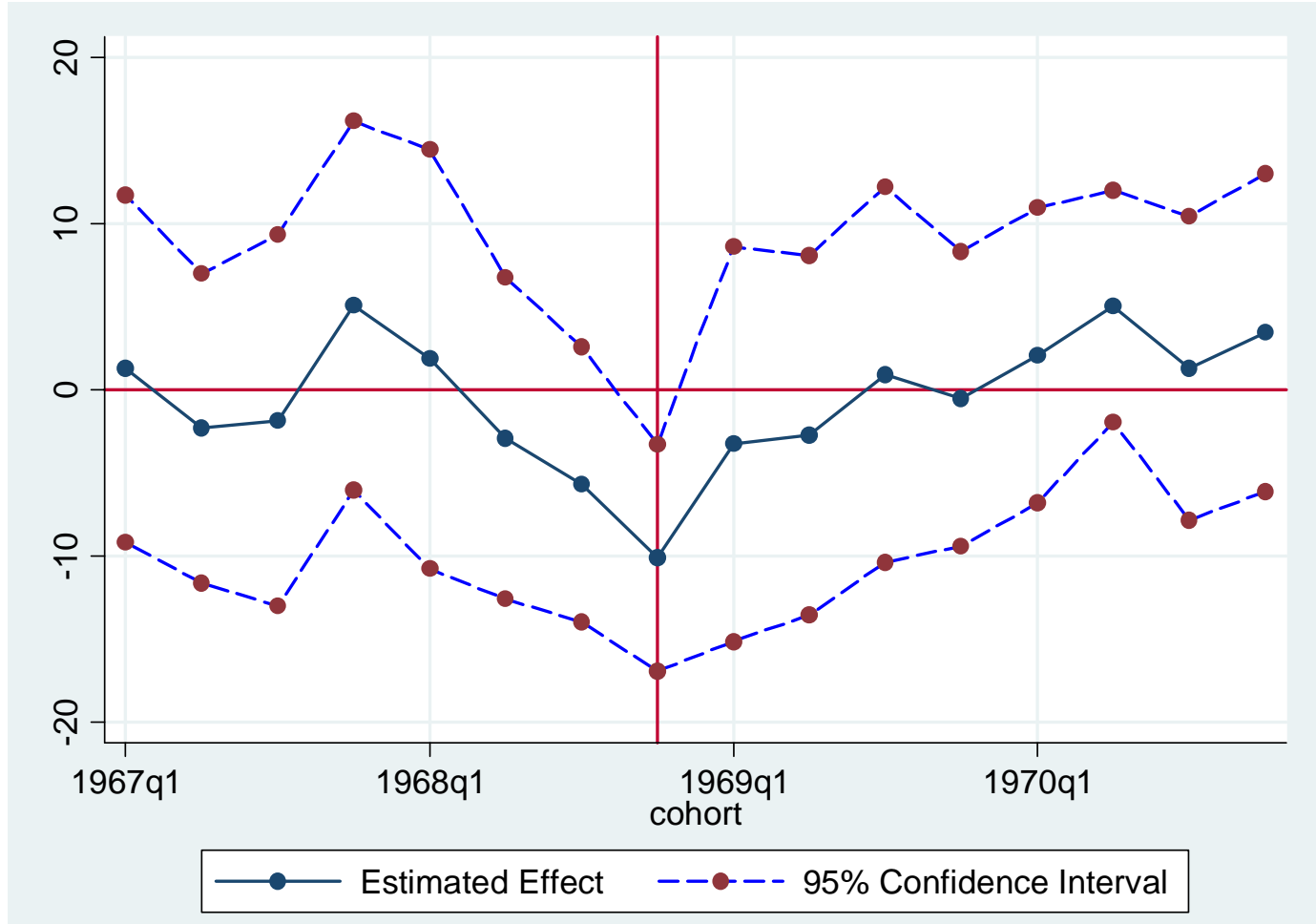

Source: Muestra Continua de Vidas Laborales (MCVL) Sample of Native Males who are High School dropouts (born between 1965 and 1972 and start working before age 20). 
Figure 10. Logarithm of yearly earnings: placebo test, 2 cohort-years bandwidth

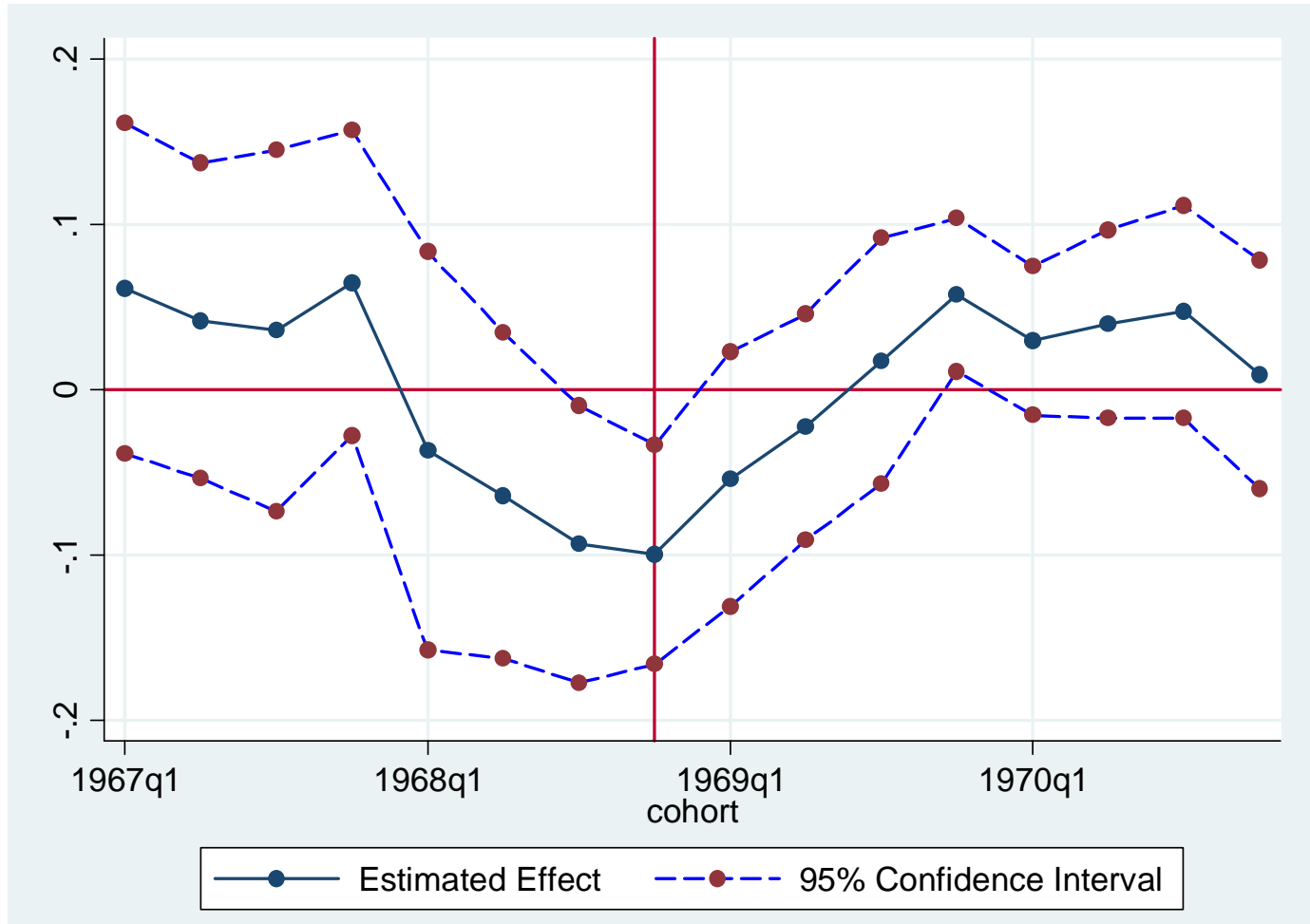

Source: Muestra Continua de Vidas Laborales (MCVL) Sample of Native Males who are High School dropouts (born between 1965 and 1972 and start working before age 20). 


\section{APPENDIX}

Table 13. Aggregation of sectors in the economy.

\begin{tabular}{ll}
\hline Sector of the economy & Description of sector \\
\hline $\begin{array}{l}\text { High Tech. } \\
\text { Manufacturing }\end{array}$ & $\begin{array}{l}\text { Manufacturing using capital intensive and ICT } \\
\text { technologies (Chemical industry, electrical industry, } \\
\text { etc.) }\end{array}$ \\
\hline $\begin{array}{l}\text { Low Tech. } \\
\text { Manufacturing }\end{array}$ & $\begin{array}{l}\text { Manufacturing with low capital intensity (Furniture, } \\
\text { Plastics, etc.) }\end{array}$ \\
\hline High Tech. Services & $\begin{array}{l}\text { Transport, Telecommunication, Finances, Education, } \\
\text { Health, etc. }\end{array}$ \\
\hline Trade & Wholesale trade, retail. \\
\hline & Hotels, restaurants, etc. \\
\hline Other Low Tech. & $\begin{array}{l}\text { Labor intensive Services (water and waste treatment, } \\
\text { personal services), Agriculture, Energy Industry }\end{array}$ \\
\hline Construction & Building activities \\
\hline Public Administration & $\begin{array}{l}\text { All public activities but health and education. Real } \\
\text { S Real State }\end{array}$ \\
\hline Missing & No information about sector of activity \\
& \\
\hline
\end{tabular}

Source: Muestra Continua de Vidas Laborales (MCVL). 
Figure 11. Share of individuals who find the first job at age 16 by cohort and share of individuals who find the first job at age 15 or before by cohort.

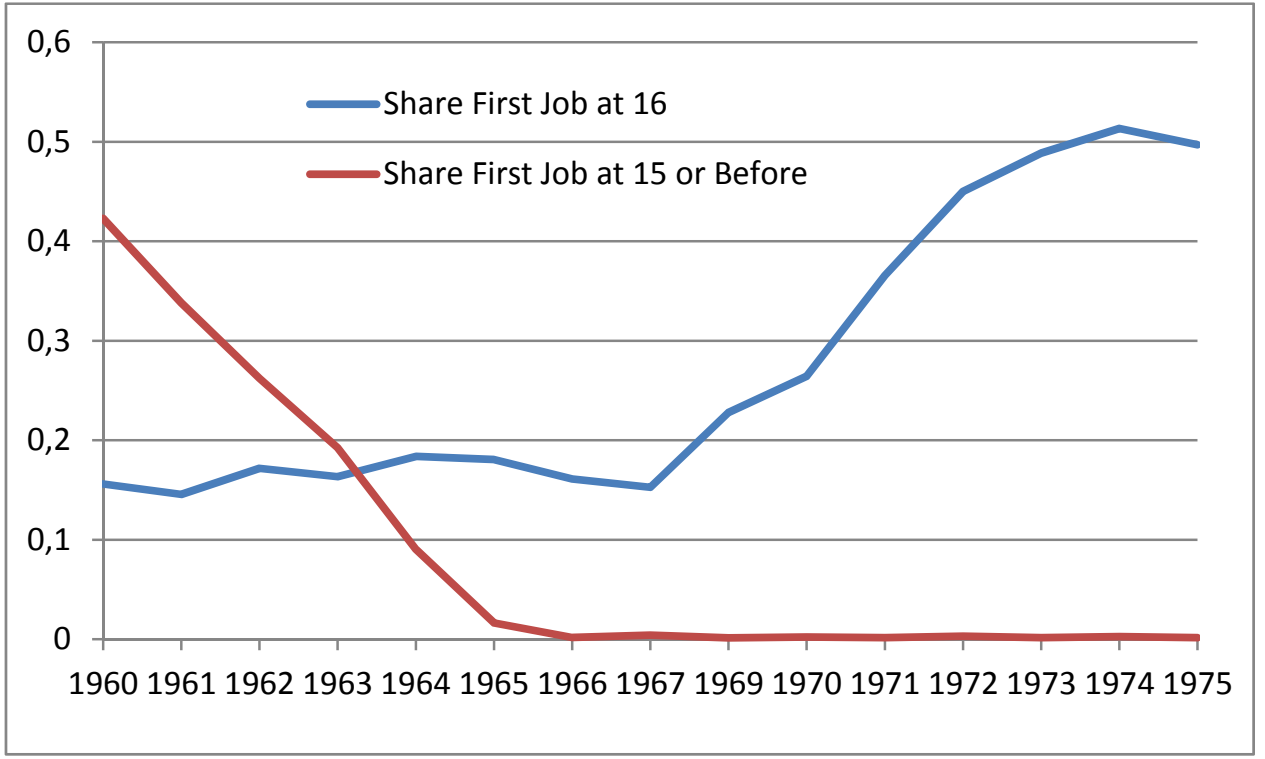

Source: Muestra Continua de Vidas Laborales (MCVL). 
Figure 12. Number of days worked per year: placebo test

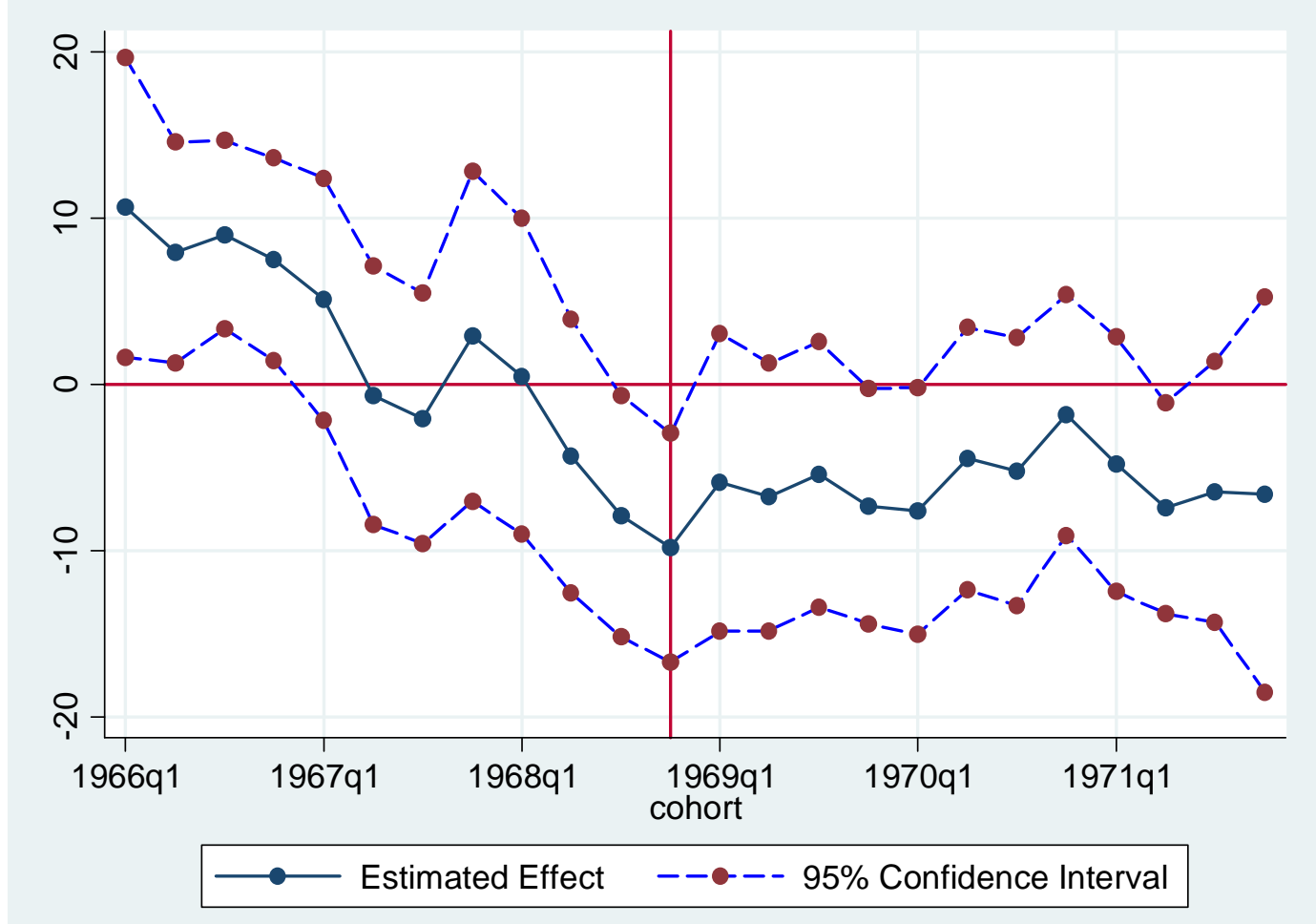

Source: Muestra Continua de Vidas Laborales (MCVL). 
Figure 13. Log yearly earnings: placebo test

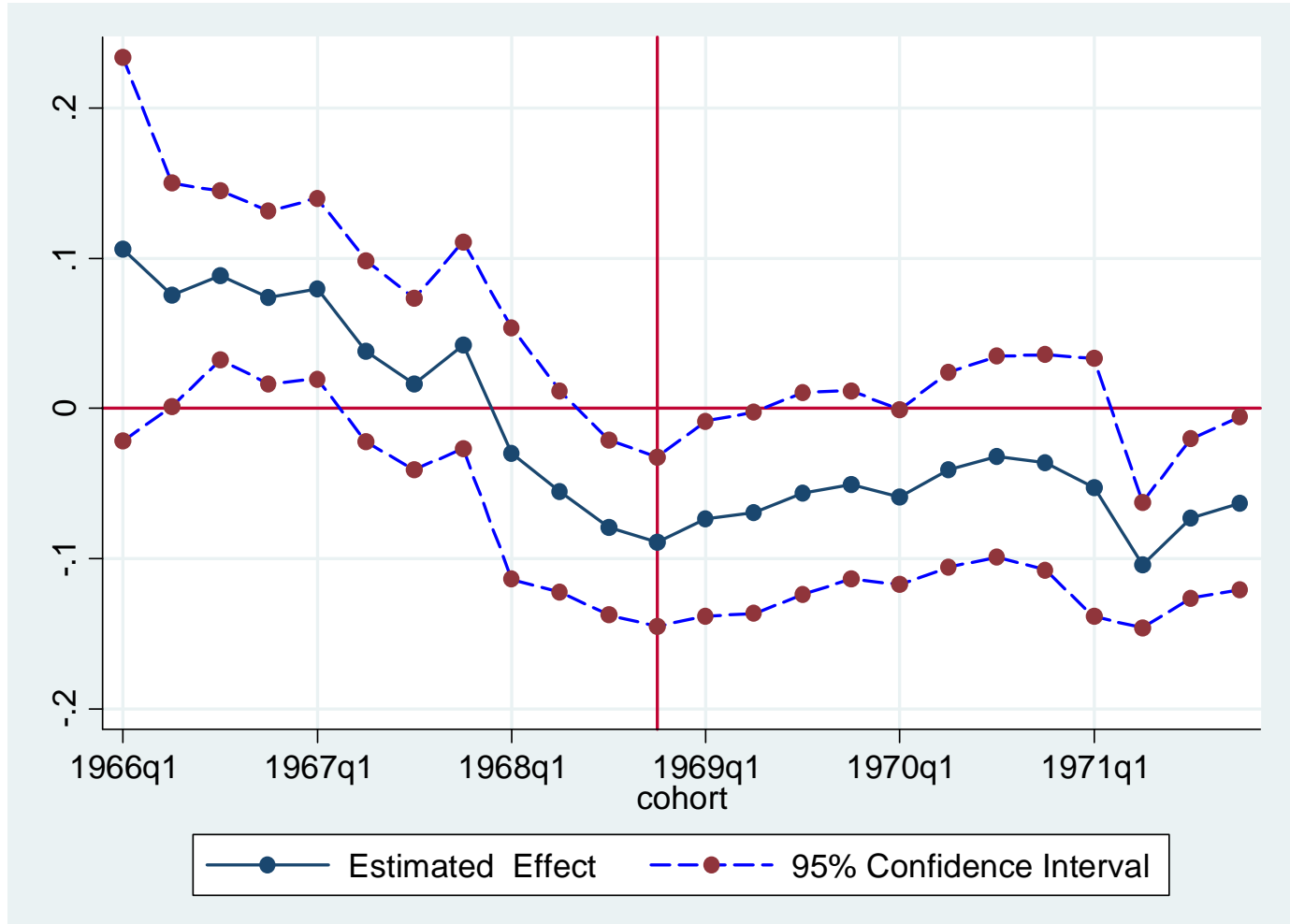

Source: Muestra Continua de Vidas Laborales (MCVL). 